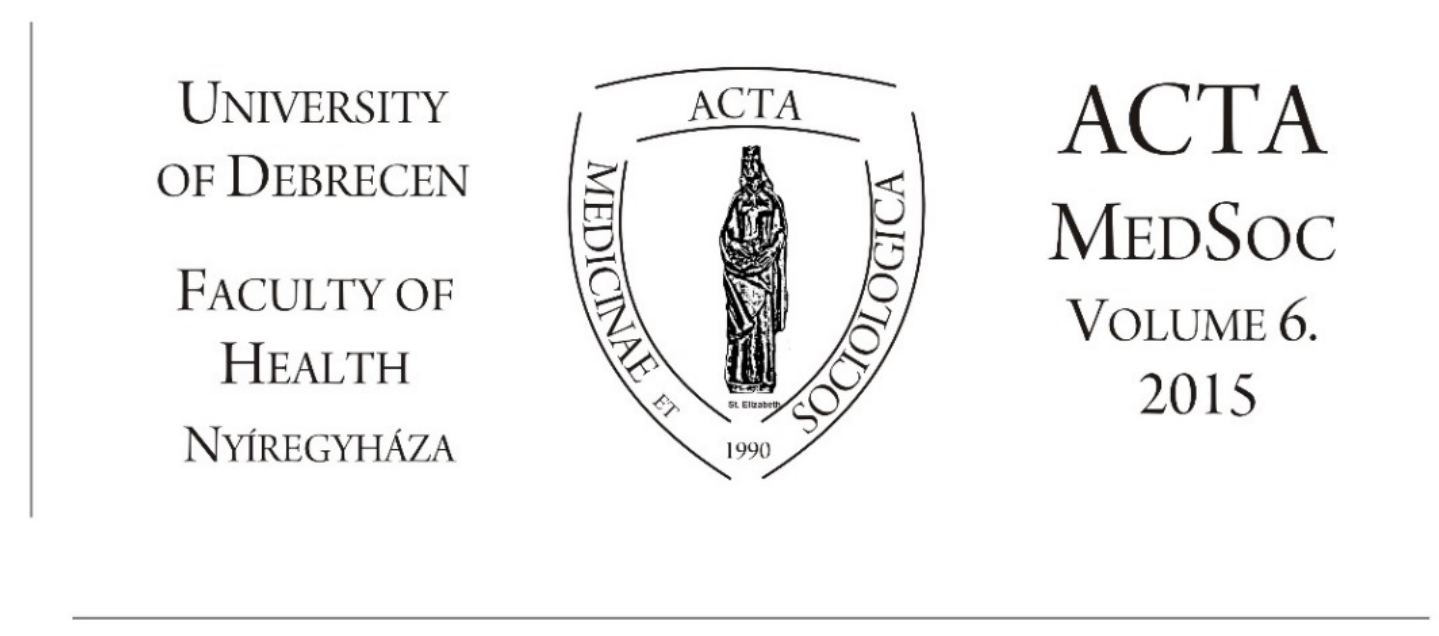

\title{
A Nyíregyházi Háztartáspanel életminőségi modellvizsgálatok legújabb eredményei, valamint az életminőség modell bővítésének lehetőségei a Rough Set Theory alkalmazásával
}

\author{
Takács Péter - Fábián Gergely - Szigeti Fruzsina
}

\begin{abstract}
Absztrakt: A negyedik háztartáspanel vizsgálat a nyíregyházi minta mellett a Nyíregyházi járás településeit is érintette. 2015-ben újra meghatározásra kerültek az előző évek módszertanát követve - az FT lokális életminőség index értékei is. A kutatási célok között szerepelt a korábban elvégzett elemzések megismétlése és a városi, járási viszonyok összehasonlítása. Az új kérdőív tartalmazta az Oxford Boldogságmérő kérdőívet, amely alkalmazásának célja az életminőség modell teljesebbé tétele volt. A felsorolt vizsgálatokon kívül a dolgozat leírja az életminőség modell fejlesztésére tett, első elemző lépések eredményeit. Ennek kapcsán előtérbe kerül a sorrendi (ordinális) típusú változók aggregálásakor felvetődő összegzési probléma egyik lehetséges megoldási módja, a Rough Set Theory alkalmazása.
\end{abstract}

Kulcsszavak: Nyíregyháza, panelfelmérés, életminőség vizsgálatok, FT index, Rough Set Theory, RST, életlen / közelítő halmazelmélet

Abstract. The latest results of Nyíregyháza Household Panel model of quality of life studies and using the possibilities of Rough Set Theory expanding the quality of life model. The fourth household panel study focuses on sample in Nyíregyháza and sample in towns of Nyíregyháza district as well. It has been re- 
calculated - following the methodology of previous years - the values of the FT local quality of life index in 2015. Among the research aims were repetition of previously performed analysis and comparison of urban and district conditions. The new survey included the Oxford Happiness questionnaire. The reason for this was to make the quality of life model more complete. This paper describes the analytical results of the first steps taken to improve the model. We examined the aggregation problem of ordinal scales and we used the results of the Rough Set Theory to solve it.

Keywords: Nyíregyháza, household panel survey, quality of life studies, FT index, Rough Set Theory

\section{Bevezetés}

Az Európai Unióban 2009-ben kiadott Stiglitz-Sen-Fittoussi jelentés (Stiglitz, Sen, Fitoussi, 2009) megerősítette azokat a kutatási irányokat, amelyek szerint az emberi életminőség - a kutatók számára mérhető - fogalmát különböző területekről (gazdaság, egészség, család, stb.) származó komponensekből érdemes kialakítani. Az Egyesült Államokban már korábban, a kétezres évek elején hasonló kutatások kezdődtek, aminek eredményei a Calvert-Henderson-féle (napjainkban Ethical Markets quality of life indicators - EMQLI (2012) - néven jegyzett) életminőségi mutatók lettek (Kárpáti, 2014). Az ilyen elméleti modellek jellegzetessége, hogy az életminőséget a komponensek súlyozott összegeként közelítik meg. Ilyen súlyozó, összegző modellt alakítottak ki T. Rahman és munkatársai is a 2005-ös években (Rahman et al., 2005), amely 8 területet jelölt meg a mérésére.

A nyíregyházi panelvizsgálatok első három hullámában (2008-2010-2012) a Rahman-féle modellre alapozott lokális életminőség index (FT Index) kialakítására került sor, amely hét területet fedett le a Rahman-féle modellböl (Takács, Fábián, 2012), (Takács, Fábián, 2014). A Nyíregyházára vonatkozó részterületi indikátorok a kutatás kezdetén született előzetes tanulmányok és konzultációk alapján kerültek kijelölésre. Később összetettebb elemzések is születtek az egyes területeken. Az 1. táblázat összefoglaló felsorolást tartalmaz azokról a forrásokról, amelyek bővebb betekintést engednek az FT index részterületeinek mélyebb összefüggéseibe.

1. táblázat. Az FT életminőség index részterületei és kapcsolódó források a korábbi hullámokban. A római számok a Rahman alapmodell szerint területeket jelölik, az F-fel kezdödö jelölés a nyíregyházi felmérés közvetlen jelölései.

I. F1 Családi, baráti viszonyok (Huszti, 2012), (Huszti, 2014) (jelen kiadványban Huszti, 2015)

II. (F8) Érzelmi jólét - első három hullámban nincs mérve (jelen kiadványban Szigeti, Fábián, Takács, 2015)

III. F2 Egészségi állapot (Jóna, Jávorné, 2012), (Erdei, R. Fedor, 2014) (jelen kiadványban Hüse, 2015)

IV. F4 Anyagi jólét (Fábián, Takács, 2012), (R. Fedor, 2012)

(Fábián, Takács, Szigeti, 2014) (jelen kiadványban Fábián, Takács, Szigeti, 2015) 
V. F6 Lokális közösség (Huszti, 2012), (Huszti, 2014)

(jelen kiadványban Huszti, 2015)

VI. F3 Munka és aktivitás (Patyán, 2012), (R. Fedor, Jávorné, 2014)

(jelen kiadványban Patyán, 2015)

VII. F7 Személyes biztonság (Balogh, Fábián, 2012), (Balogh, Fábián, 2012),

(Balogh, R. Fedor, 2014)

(jelen kiadványban Krizsai, T. Csatlós, 2015)

VIII. F5 Környezet minősége (Szoboszlai, 2012), (Szilicsány, 2014),

(Szoboszlai, 2014)

(jelen kiadványban Szilicsány, 2015)

A negyedik felmérés az FT index szempontjából megismételte az első három adatfelvétel méréseit, és két jelentős lépéssel bővítette a kutatás lehetőségeit. Az egyik lépés a modellből eddig hiányzó nyolcadik terület mérése az Oxford Boldogságkérdőív kérdéseivel (Hills, Argyle, 2002); a másik pedig a Nyíregyháza lakosságát lefedő felmérés bővítése a Nyíregyházi járás településein elvégzett kutatással.

Az adatok rendezése és tisztítása után kialakított adatbázisra alapozva első lépésben a modell alapparaméterei és maguk az FT életminőség indexek kerültek meghatározásra. Mivel három területre, a teljes mintára, valamint annak két részére is értelmezhető az FT index, ezért párhuzamosan három szinten folytak a számítások. A nyíregyházi részminta eredményei lehetővé tették a korábban megfigyelt összefüggések vizsgálatát és ellenőrzését. A járási adatok összehasonlítási alapot jelentettek földrajzi / területi szinten: azon kérdésekre adtak választ, hogy Nyíregyháza környezetében érvényesek-e azok az összefüggések, amelyeket a korábbi és a jelenlegi felmérésekben Nyíregyházán megfigyelhetők voltak. Az eredmények bemutatása a fentiekben leírt témákat tárgyalja, majd ezt követően a modell további bővítésének előkészítő számításai kaptak helyet a dolgozatban. Itt a hagyományos statisztikai vizsgálatok mellett egy új, jelenleg még kevéssé alkalmazott Rough Set Theory módszer (RST) (Csajbók, 2013) és számítási lehetőségei (Riza et al., 2014) is röviden bemutatásra kerülnek.

\section{Módszerek}

A „Nyíregyháza Életminősége 2015” kutatás mintavételi jellemzői jelen kiadvány bevezető részében szerepelnek. Nyíregyháza város és a környező települések demográfiai helyzetképét a kötetben Malakucziné Póka Mária mutatja be (M. Póka, 2015).

2015-ben az FT életminőség index kialakítása ugyanazzal a módszerrel történt, mint a korábbi hullámokban. Az alkalmazott Rahman modell (Rahman et al., 2005) nyolc olyan területet jelöl ki, amely a súlyozott indexet kialakítja. (1. ábra) 
1. ábra. A teljes Rahman modell (Kovács, 2007), (Kovács és mtsai, 2006)

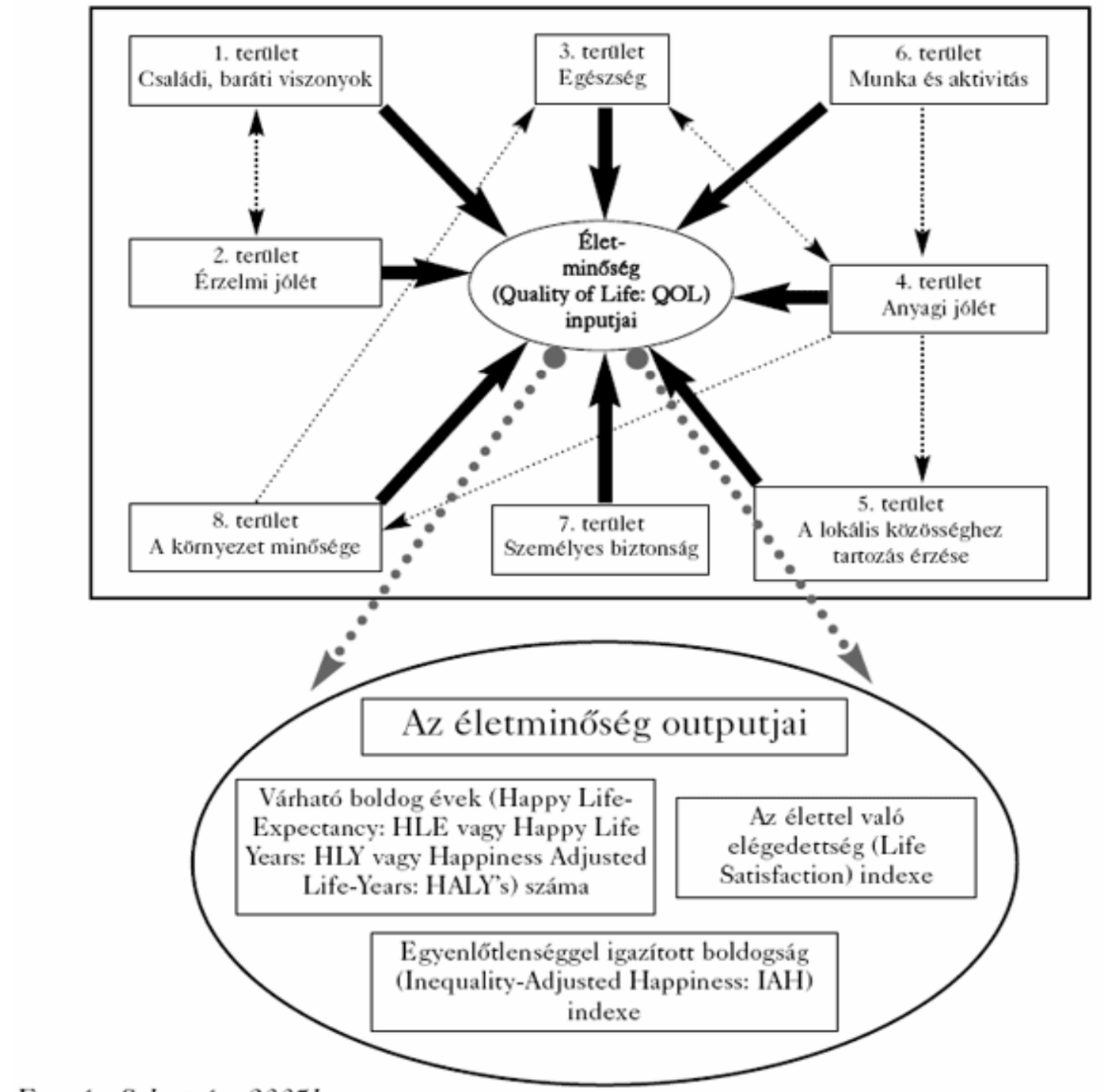

Forrás: Sebestyén, $2005 b$

A modell matematikai alakja a következő:

$$
Q O L=\alpha+\beta_{1} D_{1}\left(x^{1}\right)+\beta_{2} D_{2}\left(x^{2}\right)+\ldots+\beta_{8} D_{8}\left(x^{8}\right)+\varepsilon
$$

Jelölések: $\quad Q O L-$ Qality of Life, Életminőség

$\alpha-$ konstans tag

$\beta_{1}-\beta_{8}-$ súlyszámok vektorai

$D_{1}-D_{8}-$ részterületek indikátorai (összevont változók -1 .

ábra)

$x^{1}-x^{8}-$ részterületeken belül mért változók halmazai

$\varepsilon$ - hibatényezö

A modellbeli súlyok kialakításának folyamata és a modell többi paraméterének kiszámítása a hivatkozott Rahman-féle dolgozatban részletesen szerepel. A 4. hullámban három FT index kialakítására került sor. Első lépésben minden résztvevőre (teljes minta) vonatkoztatva, majd külön a városi- (nyíregyházi), és 
külön a járási (Nyíregyháza járás települései) almintára kalkulálva. Az FT indexel kapcsolatban - szinkronban a korábbi hullámokkal - a következő változók kerültek vizsgálatra:

1. nem (kétértékü változó);

2. életkor (folytonos változó)

3. minta (város / járás; kétértékü változó);

4. családi állapot (öt lehetséges érték);

5. egészségi állapot (öt lehetséges érték);

6. munkahely megléte (kétértékü változó);

7. foglalkozás típusa (17 típus);

8. foglalkoztatás módja (öt lehetséges érték);

9. havi jövedelemmel való elégedettség (hat lehetséges válasz);

10. gépkocsi tulajdonjoga (három értékủ változó);

11. vallási közösséghez való tartozás (kétértékü változó);

12. idegen nyelv ismerete (kétértékü változó);

13. iskolai végzettség (kilenc szint);

14. bünözés, vandalizmus (kétértékü változó);

15. hiba a lakásban (kétértékủ változó)

Az egyes változók lehetséges értékei az eredmények ismertetésekor közölt táblázatokban vannak részletezve.

Az elemzések során a kétértékủ változók esetén kétmintás t-próba és Mann-Whitney teszt; a kettőnél több értéket felvehető változók esetében pedig egyszempontos varianciaanalízis (ANOVA) és Kruskal-Wallis teszt került alkalmazásra. A kereszttáblás elemzések során khí-négyzet próba és szükség esetén Fisher-féle egzakt teszt módszere került felhasználásra. Alkalmazott statisztikai programok: Microsoft Excel 2002; IBM SPSS v.22.

Az Oxford Boldogságkérdőív feldolgozására és a modellbe való illesztésére a hagyományosnak nevezhető lineáris regresszió eljárása és az új módszernek számító Rough Set Theory (RST, magyar elnevezése még nem rögzült, talán az Életlen vagy Közelítő Halmazelmélet név honosodik meg hazánkban) került alkalmazására, amely a sorrendi (ordinális) mérési szintü változók feldolgozási lehetőségeit növeli. Az Oxford kérdések összevonhatóságának vizsgálata egy különálló, az érzelmi állapotot mérő, szintén hatértékü változón keresztül történt (,Amennyiben jellemeznie kellene saját érzelmi állapotát, mit mondana róla?” hatértékủ változó).

A sorrendi skálák esetén a legfőbb kritérium a mért értékek sorrendbe rendezhetősége. Ez olyan feltétel, ami általában igen könnyen teljesíthető, és ezért az ilyen típusú vizsgálatok széles körben alkalmazásra találnak. Az elemzések első lépésében az egyes válaszlehetőségek gyakoriságai, relatív gyakoriságai kerülnek meghatározásra; ezek ábrázolására általában az oszlopdiagramok különféle válfajai használatosak. A központi tendenciát a medián vagy a módusz méri. A szóródás mutatói általában a terjedelem és a kvartilisek (Q1, Q3) közötti különbség. Az elemzések során minden változó elöször külön-külön kerül elemzésre, majd a változópárok közötti kapcsolat feltárására kerül sor. Néhány kapcsolódó nem- 
parametrikus teszt: khí-négyzet próba, Mann-Whitney teszt, Wilcoxon előjeles rangteszt, Kruskal-Wallis teszt. Ezt követően az egyedi változók összevonásra kerülhetnek a vizsgálandó komplex fogalmak modell alapú közelítésére.

Az Oxford Boldogságkérdöív 29 kérdése esetén is a fentiek voltak az irányadók (1-6 fokozatú sorrendi skálák). A kérdések egy része érzelmileg emelkedő tendenciájú válaszokat, más része viszont csökkenőket tartalmazott. A negatív sorrendet át kellett forgatni az összevonás érdekében. Ezt követően került sor a kérdéssor válaszainak átlagolására.

Az eljárás viszont egy „rejtett csapdát” tartalmaz; ekkor fordulhatnak elő azok az esetek, amikor például az egyik változó 1, a másik változó 5 értéke ugyanúgy 6-os összeget (vagy hármas átlagot) ad, mint amikor az első változó vesz fel 5, a második 1 értéket.

A sorrendi (és általában a diszkrét valószínüségi) változók elemzésének egy másik, informatikai eredetü megközelítését adja a Rough Set analízis. A módszer eljárásai kiküszöbölik a fentebb említett hátrányokat. Az RS elméletet az 1980-as évek elején javasolta Z. Pawlak lengyel matematikus (Pawlak, 1982). Pawlak és munkatársai révén kialakultak az elmélet keretei, és számos területen találtak alkalmazásra az elemzési módszerek. Napjainkban tovább folyik az elméleti kutatás; valamint annak lehetünk tanúi, hogy egyre szélesebb körüek az alkalmazási területek, egyre ismertebbé válnak az ilyen irányú elemzési lehetőségek. 2014-ben jelent meg az R statisztikai rendszerben az a programcsomag (RoughSets; Riza et al., 2014), amely az RST számításokat igen megkönnyíti. Az Oxford Boldogságkérdőív elemzése (R 3.0.3. + RoughSets csomag) során a hiányzó értékek kezelésére (Missing Value Completion) és a további elemzés szempontjából értékes változók kiválasztása (Feature Selection) került előtérbe. A Feature Selection eljárás azokat a változókat jelöli, meg, amelyek ugyanazt az információt képviselik, mint a teljes változókészlet.

\section{Eredmények}

Az FT index kialakításakor, a változók összevonása és modellbe építése során a főkomponens elemzésekből nyert súlyozó változók kerültek a modellbe. A korábbi számítási eredmények és az új adatokból számított értékek a 2. táblázatban láthatók. Az F2 és F4 paraméterek a korábbi évekhez hasonlóan nem jelentenek súlyozó tényezőt (változatlanul hagyják a bevont változót; egyetlen változó bevonását jelölik a modellben). A paraméterek évenkénti viselkedését tekintve az látható, hogy míg F7 (változás: + 0,264), F6 (változás: + 0,168), F3 (változás: + 0,121) és F1 (változás: $+0,067$ ) értékei növekedtek; addig F5 (változás: - 0,127) csökkent. 
2. táblázat. Az FT életminöség index belső együtthatói, 2008-2015. Csoportok (a római számok az eredeti Rahman-féle sorrendet jelölik): F1 - I. Családi, baráti viszonyok; II. Érzelmi jólét (nincs mérve); F2 - III. Egészségi állapot; F4 - IV. Anyagi jólét; F6 - V. Lokális közösség; F3 - VI. Munka és aktivitás; F7 - VII. Személyes biztonság; F5 - VIII. Környezet minösége.

\begin{tabular}{|l|c|c|c|c|c|c|c|}
\hline & F1 - I. & F2 - III. & F3 - VI. & F4 - IV. & F5 - VIII. & F6 - V. & F7 - VII. \\
\hline 2008 & 1,376 & 1 & 1,007 & 1 & 1,710 & 1,471 & 1,718 \\
\hline 2010 & 1,330 & 1 & 1,006 & 1 & 1,713 & 1,428 & 1,788 \\
\hline 2012 & 1,394 & 1 & 1,013 & 1 & 1,913 & 1,657 & 1,808 \\
\hline 2015 város & 1,443 & 1 & 1,128 & 1 & 1,583 & 1,639 & 1,982 \\
\hline Átlag & 1,386 & 1 & 1,039 & 1 & 1,730 & 1,549 & 1,824 \\
\hline 2015 járás & 1,541 & 1 & 1,073 & 1 & 1,384 & 1,756 & 1,964 \\
\hline 2015 összes & 1,476 & 1 & 1,087 & 1 & 1,554 & 1,678 & 1,964 \\
\hline Átlag & 1,427 & 1 & 1,052 & 1 & 1,643 & 1,605 & 1,871 \\
\hline
\end{tabular}

Forrás: Nyíregyháza Életminősége 2015

A már összesített FT index átlagértékeit és leíró statisztikai jellemzőit a korábbi évekre és 2015-re vonatkoztatva az 3. táblázatban kaptak helyet. A nagyobb indexérték magasabb életminőséget jelez. A lokális életminőség index terjedelme 25-31 között változik. Átlagosan 6 körül ingadozik, a szórás egyenletesen 4 körüli. A táblázat adatai az életminőség átlagát tekintve 2010-től növekedést mutatnak. Az életminőség átlagára vonatkozó konfidencia-intervallumok szinte minden esetben egymást átfedők; szignifikánsan kiugró növekedés vagy csökkenés nem figyelhető meg. A szóródási mutatók egyenletes képet mutatnak.

3. táblázat. Az FT életminőség index évenkénti (2008-2015) leíró statisztikai jellemzése

\begin{tabular}{|l|l|l|l|l|l|l|}
\hline & 2008 & 2010 & 2012 & $\begin{array}{l}2015 \\
\text { város }\end{array}$ & $\begin{array}{l}2015 \\
\text { járás }\end{array}$ & $\begin{array}{l}2015 \\
\text { összes }\end{array}$ \\
\hline Átlag & $\mathbf{6 , 0 8 7 0}$ & $\mathbf{5 , 7 6 8 2}$ & $\mathbf{6 , 3 4 0 1}$ & $\mathbf{6 , 7 5 5 7}$ & 6,0976 & 6,3864 \\
\hline $\begin{array}{l}\text { 95\% konfidencia } \\
\text { intervallum az } \\
\text { átlagra (alsó, } \\
\text { felső határ) }\end{array}$ & 5,8680 & 5,3850 & 6,0772 & 6,4504 & 5,8055 & 6,1727 \\
\cline { 2 - 7 } & 6,3060 & 6,1514 & 6,6029 & 7,0610 & 6,3897 & 6,6002 \\
\hline $\begin{array}{l}\text { 5\%-os vágott } \\
\text { átlag }\end{array}$ & 6,0925 & 5,7658 & 6,2567 & 6,7384 & 5,9392 & 6,3240 \\
\hline Medián & 6,1574 & 5,6503 & 6,0278 & 6,9109 & 5,7167 & 6,2429 \\
\hline Szórásnégyzet & 20,885 & 18,102 & 19,273 & 17,468 & 19,775 & 19,196 \\
\hline Szórás & 4,57006 & 4,25467 & 4,39014 & 4,18161 & 4,44693 & 4,38131 \\
\hline Minimum & $-6,48$ & $-10,82$ & $-5,98$ & $-5,92$ & $-6,74$ & $-8,29$ \\
\hline Maximum & 21,21 & 18,68 & 19,24 & 22,20 & 24,89 & 20,82 \\
\hline Terjedelem & 27,69 & 29,5 & 25,22 & 28,12 & 31,63 & 29,11 \\
\hline
\end{tabular}




\section{Nemek közötti különbségek}

A válaszadó városi minta 38,0\%-a férfi, 62,0\%-a nő volt. A járási mintában ugyanezen arány 35,6\%-64,4\% volt. Az arányokat összevetve, nem mutatkozott szignifikáns eltérés a két részmintában $\left(\chi^{2}(1, N=1642)=1,029, p=0,310\right)$. A teljes mintában a férfi-nő arány 36,7\%-63,3\% volt.

Az FT életminőség index értékeit tekintve a férfiak és a nők körében szignifikáns eltérés adódott. Az eltérés mind a járási, mind a teljes mintát figyelembe véve ugyanúgy kimutatható volt; a városi körben azonban nem. Lásd 4. táblázat.

\section{4. táblázat. Az FTI érték megoszlása férfiak, nök körében}

a teljes-és a két részmintában

\begin{tabular}{|c|c|c|c|c|c|c|c|c|}
\hline & Nem & $\mathrm{N}$ & $\begin{array}{l}\text { FT } \\
\text { Mean }\end{array}$ & $\begin{array}{l}\text { Std. } \\
\text { Deviation }\end{array}$ & $\begin{array}{l}\text { Std. Error } \\
\text { Mean }\end{array}$ & $\begin{array}{l}\text { Kétmintás } \\
\text { t-próba p }\end{array}$ & $\begin{array}{l}\text { Rang- } \\
\text { átlagok }\end{array}$ & $\begin{array}{l}\text { Mann- } \\
\text { Whitney } \\
\text { p }\end{array}$ \\
\hline \multirow{2}{*}{ Teljes } & Férfi & 586 & 7,3239 & 4,64824 & 0,19202 & \multirow{2}{*}{0,000} & 888,54 & \multirow{2}{*}{0,000} \\
\hline & Nő & 1017 & 5,8576 & 4,13858 & 0,12977 & & 752,14 & \\
\hline \multirow{2}{*}{ Város } & Férfi & 273 & 6,8234 & 4,03407 & 0,24415 & \multirow{2}{*}{0,767} & 364,05 & \multirow{2}{*}{0,573} \\
\hline & Nő & 443 & 6,7280 & 4,27721 & 0,20322 & & 355,08 & \\
\hline \multirow{2}{*}{ Járás } & Férfi & 313 & 7,2730 & 4,83824 & 0,27347 & \multirow{2}{*}{0,000} & 505,15 & \multirow{2}{*}{0,000} \\
\hline & Nő & 574 & 5,4550 & 4,09800 & 0,17105 & & 410,65 & \\
\hline
\end{tabular}

Forrás: Nyíregyháza Életminősége 2015

\section{Életkor}

Az életkor a járási és városi részmintában statisztikailag megegyezett (kétmintás tpróba, $\mathrm{t}=0,593 ; \mathrm{df}=1596 ; \mathrm{p}=0,553$; Mann-Whitney teszt, $\mathrm{p}=0,602)$. A városi lakosság átlagéletkora 50,35 év (95\% CI [49,14-51,56]), a járásiak átlagéletkora 49,87 év (95\% CI [48,81-50,92]) volt.

\section{Az FTI járási és városi különbségei, települések átlagértékei}

A paraméteres és nem paraméteres vizsgálatok eredményei szerint az FT index szignifikánsan magasabb érékünek mutatkozott a városi lakosság körében (város FTI átlag $=6,997$; járás FTI átlag $=5,892 ;$ kétmintás t-próba; $\mathrm{t}=5,077 ; \mathrm{df}=1614 ; \mathrm{p}=$ 0,000; átlagok közötti különbség = 1,104; Mann-Whitney teszt; $\mathrm{p}=0,000$ ).

A járás / város összevetést részletesebben - település szinten - vizsgálva pontosabb kép alakítható ki az életminőség index tekintetében. A vizsgálatba bevont tizenhárom település közül szignifikánsan magasabb és alacsonyabb FT index átlagértékek voltak megfigyelhetök (ANOVA; $F=10,402 ;$ df $=12 ; p=0,000$; Kruskal-Wallis teszt; $\left.\chi^{2}=122,64 ; \mathrm{df}=12 ; \mathrm{p}=0,000\right)$. Az FTI átlagértékek eloszlását az 2. ábra szemlélteti. Az ábra tükrözi, hogy Nyírpazony $(10,14)$ és Sényő $(9,04)$ az a két település, amelyben az FTI értékei szignifikánsan magasabbak. Timáron az FT index értéke $(3,40)$ szignifikánsan alacsonyabb a többi település értékeinél. A Timárra vonatkozó eredményt a kis elemszám $(\mathrm{n}=3)$ miatt óvatosan kell kezelni. A három kiugró értéket figyelmen kívül hagyva (a 2. ábrán a legalacsonyabb és legmagasabb vonal alatti és feletti települések) a szignifikáns különbség az egyes 
települések között megmaradt (ANOVA; $\mathrm{F}=6,699 ; \mathrm{df}=9 ; \mathrm{p}=0,000$; Kruskal-Wallis tesz; $\chi^{2}=70,533 ; \mathrm{df}=9, \mathrm{p}=0,000$ ). Ekkor Nyíregyháza, Nyírtura és Apagy azok a települések, amelyek magasabb FTI értéket mutatnak, de közöttük nem szignifikáns az eltérés. Szignifikánsan kisebb viszont Kótaj, Napkor, Nyírtelek és Újfehértó FTI értéke Nyíregyházához viszonyítva. Alacsonyabb, de nem szignifikánsan Nyíregyházához képest Apagy, Kálmánháza, Nagycserkesz, Nyírtura, Rakamaz.

2. ábra. Az FTI átlagok alakulása az egyes településeken. $A$ vizszintes vonalak a szignifikánsan magasabb és alacsonyabb FTI átlagértékkel

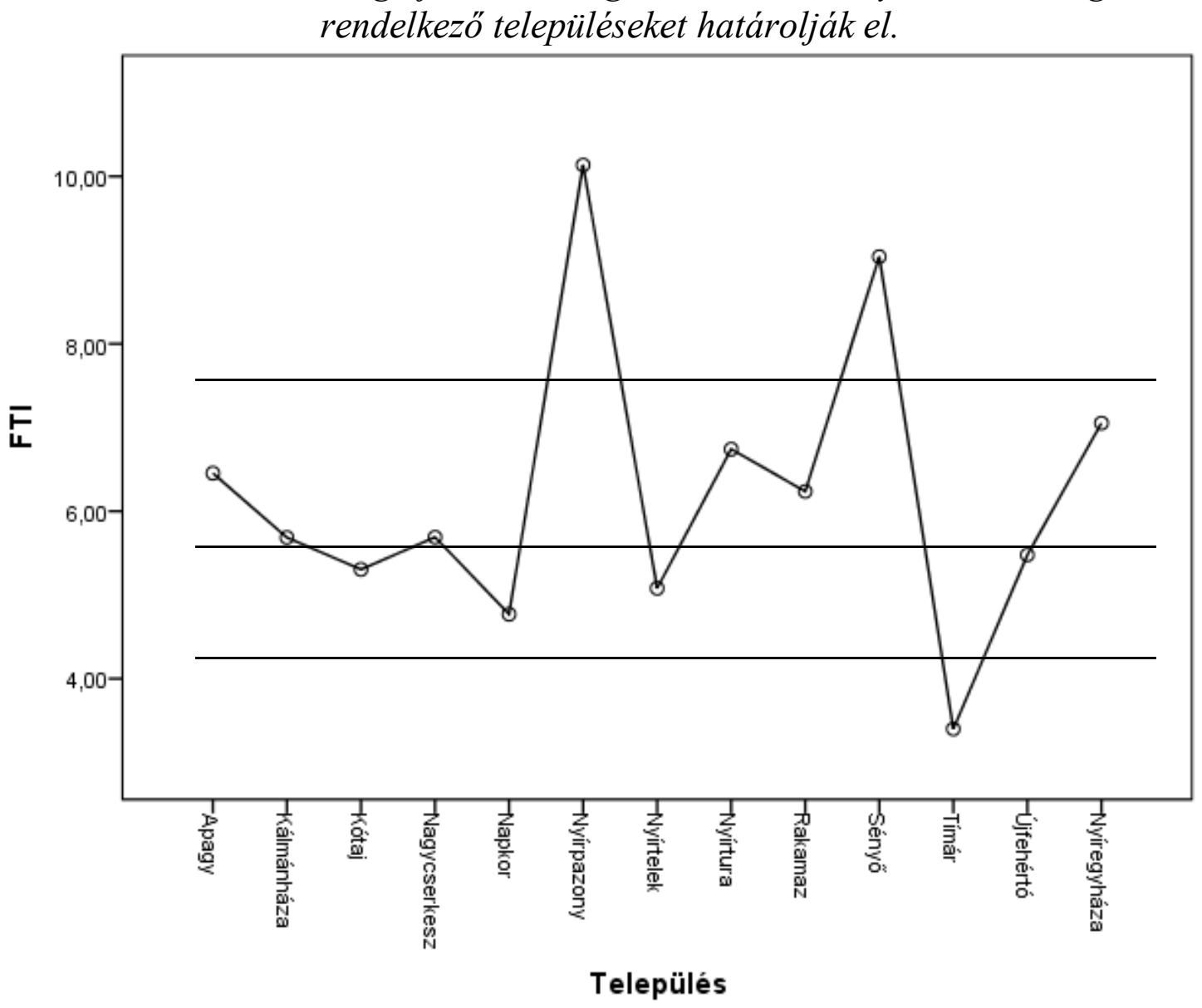

Forrás: Nyíregyháza Életminősége 2015

\section{Családi, baráti viszonyok (Rahmann I. - Nyíregyházi HáztartásPanel - NyHP} F1)

A válaszadók családi állapot szerinti megoszlását városi/járási bontásban az 5 . táblázat tartalmazza. A teljes mintában a legnagyobb arányban a házasságban élők vannak. Mind a városi, mind a járási lakosok között is a házasok aránya a legmérvadóbb. A statisztikai vizsgálatok eredményei nem mutattak szignifikáns különbséget a családi állapot és a városi-járási vonatkozásban $\left(\chi^{2}(4, N=1634)=2,643, p=0,619\right)$. 
5. táblázat. A családi állapot megoszlása a városi és járási

mintában

\begin{tabular}{|c|c|c|c|c|c|c|}
\hline & \multicolumn{5}{|c|}{ Családi állapota } & \multirow[b]{2}{*}{ Összes } \\
\hline & $\begin{array}{l}\text { Nötlen, } \\
\text { hajadon }\end{array}$ & Házas & Élettárssal él & Elvált & Özvegy & \\
\hline Város - fö́ & 102 & 431 & 69 & 40 & 98 & 740 \\
\hline$\%$ & $13,8 \%$ & $58,2 \%$ & $9,3 \%$ & $5,4 \%$ & $13,2 \%$ & $100,0 \%$ \\
\hline Járás - fố & 115 & 544 & 70 & 56 & 109 & 894 \\
\hline$\%$ & $12,9 \%$ & $60,9 \%$ & $7,8 \%$ & $6,3 \%$ & $12,2 \%$ & $100,0 \%$ \\
\hline Teljes - fö & 217 & 975 & 139 & 96 & 207 & 1634 \\
\hline$\%$ teljes & $13,3 \%$ & $59,7 \%$ & $8,5 \%$ & $5,9 \%$ & $12,7 \%$ & $100,0 \%$ \\
\hline
\end{tabular}

Forrás: Nyíregyháza Életminösége 2015

A különböző családi állapotú válaszadók FT index értékeit az 6. táblázat foglalja magába. A 2-4. oszlopok a városi adatokat, az 5-7. oszlopok a járási adatokat, a 810. oszlopok pedig a teljes mintára vonatkozó adatokat tartalmazzák. Mindkét részmintában és a teljes mintában is a különböző családi állapotok FT átlagai szignifikánsan különböznek (a táblázat utolsó sora mutatja az egyszempontos varianciaanalízis (Anova) és a Kruskal-Wallis teszt eredményeit).

A 3. ábra a 6. táblázat értékeit és az egyszempontos varianciaanalízist követő Post-Hoc elemzéseket szemlélteti. Mindhárom vonatkozásban (város, járás, összes) az FT index legmagasabb értéke a nőtlen / hajadon kategóriában mutatkozott. A legalacsonyabb FT indexet az özvegyek körében látható. Jellemző, hogy a társsal élők (házas, élettárssal él) - kivéve a nőtlen / hajadon kategóriát - magasabb indexértékkel rendelkeznek, mint a társ nélküliek (elvált, özvegy).

6. táblázat - A különbözö családi állapot városi-, járási részmintára és a teljes mintára vonatkozó FT index átlagértékei, rangátlagai és az elemszámok

\begin{tabular}{|c|c|c|c|c|c|c|c|c|c|}
\hline & \multicolumn{3}{|c|}{ Város } & \multicolumn{3}{|c|}{ Járás } & \multicolumn{3}{|c|}{ Összes } \\
\hline $\begin{array}{l}\text { Családi } \\
\text { állapota }\end{array}$ & $\begin{array}{c}\mathrm{FT} \\
\text { átlag }\end{array}$ & Rangátlag & $\mathrm{N}$ & FT átlag & Rangátlag & $\mathrm{N}$ & FT átlag & $\begin{array}{c}\text { Rangátl } \\
\text { ag }\end{array}$ & $\mathrm{N}$ \\
\hline $\begin{array}{l}\text { Nőtlen, } \\
\text { hajadon }\end{array}$ & 7,6926 & 402,11 & 96 & 7,7690 & 547,07 & 112 & 8,0389 & 991,23 & 208 \\
\hline Házas & 7,1096 & 372,52 & 415 & 6,3140 & 453,30 & 538 & 6,5536 & 814,00 & 953 \\
\hline Élettárssal él & 7,1017 & 379,51 & 68 & 5,9412 & 428,49 & 70 & 6,8997 & 836,24 & 138 \\
\hline Elvált & 5,0466 & 272,15 & 40 & 4,9071 & 388,11 & 56 & 5,1557 & 684,47 & 96 \\
\hline Özvegy & 4,7227 & 252,42 & 92 & 3,7514 & 317,54 & 108 & 3,9456 & 548,93 & 200 \\
\hline Összes & 6,7626 & - & 711 & 6,0666 & - & 884 & 6,3661 & - & $\begin{array}{c}159 \\
5\end{array}$ \\
\hline Módszer & Anova & $\begin{array}{c}\text { Kruskal } \\
\text { Wallis }\end{array}$ & & Anova & $\begin{array}{c}\text { Kruskal } \\
\text { Wallis }\end{array}$ & & Anova & $\begin{array}{c}\text { Kruskal } \\
\text { Wallis }\end{array}$ & \\
\hline Df & 4 & 4 & & 4 & 4 & & 4 & 4 & \\
\hline $\mathrm{F}$ & 9,577 & - & & 13,681 & - & & 27,341 & - & \\
\hline khí-négyzet & - & 38,479 & & - & 48,366 & & - & 103,028 & \\
\hline $\mathrm{P}$ & 0,000 & 0,000 & & 0,000 & 0,000 & & 0,000 & 0,000 & \\
\hline
\end{tabular}

Forrás: Nyíregyháza Életminösége 2015 
3. ábra. Az FT index átlagértékei a különbözö családi állapotokban. Az ellipszisek a Post-Hoc analízisek során kialakult egymástól nem különbözö csoportokat szemléltetik.

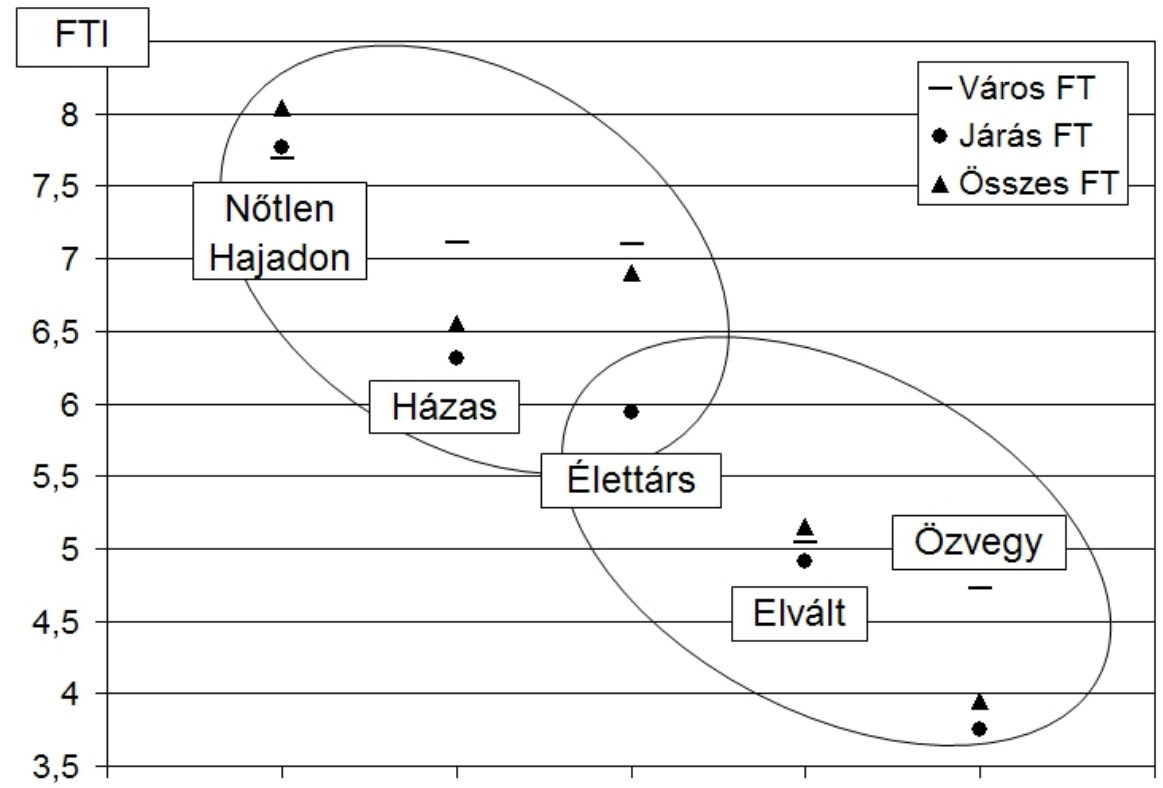

Forrás: Nyíregyháza Életminősége 2015

\section{Egészségi állapot (Rahmann III. - NyHP F2)}

Az egészségi állapot megoszlását az öt megadott kategóriában külön a városi és a járási lakosok tekintetében az 7. táblázat tartalmazza. A városi lakosság körében magasabb arányban fordul elő a „Nagyon jó” és „Jó” ítélet az egészség önmegállapításakor; a járási lakosság az „Elfogadható” és „Rossz” kategóriákat jelölte meg nagyobb arányban. A „Nagyon rossz” ítéletet ismét a városi válaszadók választották nagyobb arányban. Az eloszlások összevetésére alkalmazott khínégyzet teszt szerint szignifikáns eltérés van a két eloszlás között $\left(\chi^{2}(4, N=1636)=\right.$ $16,874, \mathrm{p}=0.002)$.

7. táblázat. A városi és járási lakosok egészségi állapotra vonatkozó kérdésre adott válaszainak eloszlása

\begin{tabular}{|l|c|c|c|c|c|c|}
\hline & \multicolumn{4}{|c|}{ Hogyan jellemezné egészségi állapotát? } & \multirow{2}{*}{ Teljes } \\
\cline { 2 - 6 } & $\begin{array}{c}\text { Nagyon } \\
\text { jó }\end{array}$ & Jó & $\begin{array}{c}\text { Elfogad- } \\
\text { ható }\end{array}$ & Rossz & $\begin{array}{c}\text { Nagyon } \\
\text { rossz }\end{array}$ & \\
\hline Város - fón & 82 & 272 & 299 & 62 & 21 & 736 \\
\hline$\%$ & $\mathbf{1 1 , 1 \%}$ & $\mathbf{3 7 , 0 \%}$ & $40,6 \%$ & $8,4 \%$ & $\mathbf{2 , 9 \%}$ & $100,0 \%$ \\
\hline Járás - fö & 76 & 296 & 384 & 125 & 19 & 900 \\
\hline$\%$ & $8,4 \%$ & $32,9 \%$ & $\mathbf{4 2 , 7 \%}$ & $\mathbf{1 3 , 9 \%}$ & $2,1 \%$ & $100,0 \%$ \\
\hline Teljes minta - fö & 158 & 568 & 683 & 187 & 40 & 1636 \\
\hline$\%$ & $9,7 \%$ & $34,7 \%$ & $41,7 \%$ & $11,4 \%$ & $2,4 \%$ & $100,0 \%$ \\
\hline
\end{tabular}


8. táblázat. A különbözö családi állapot városi-, járási részmintára és a teljes mintára vonatkozó FT index átlagértékei, rangátlagai és az elemszámok

\begin{tabular}{|c|c|c|c|c|c|c|c|c|c|}
\hline & \multicolumn{3}{|c|}{ Város } & \multicolumn{3}{|c|}{ Járás } & \multicolumn{3}{|c|}{ Összes } \\
\hline $\begin{array}{l}\text { Egészségi } \\
\text { állapota }\end{array}$ & $\begin{array}{c}\text { FT } \\
\text { átlag }\end{array}$ & Rangátlag & $\mathrm{N}$ & $\begin{array}{c}\text { FT } \\
\text { átlag }\end{array}$ & Rangátlag & $\mathrm{N}$ & $\begin{array}{l}\text { FT } \\
\text { átlag }\end{array}$ & $\begin{array}{c}\text { Rangátl } \\
\text { ag }\end{array}$ & $\mathrm{N}$ \\
\hline Nagyon jó & 9,1962 & 482,19 & 79 & 10,1001 & 681,97 & 76 & 10,2678 & 1208,95 & 155 \\
\hline Jó & 8,5062 & 451,70 & 268 & 7,8767 & 561,44 & 293 & 8,1517 & 1012,11 & 561 \\
\hline Elfogadható & 5,5769 & 298,79 & 296 & 5,3604 & 398,16 & 381 & 5,3972 & 693,77 & 677 \\
\hline Rossz & 3,4911 & 197,66 & 59 & 2,5319 & 232,18 & 124 & 2,5800 & 390,74 & 183 \\
\hline Nagyon rossz & 1,0215 & 117,76 & 21 & 0,7058 & 123,63 & 19 & 0,7453 & 254,18 & 40 \\
\hline Total & 6,7557 & - & 723 & 6,0976 & - & 893 & 6,3864 & - & 1616 \\
\hline Módszer & Anova & $\begin{array}{c}\text { Kruskal } \\
\text { Wallis }\end{array}$ & & Anova & $\begin{array}{c}\text { Kruskal } \\
\text { Wallis }\end{array}$ & & Anova & $\begin{array}{c}\text { Kruskal } \\
\text { Wallis }\end{array}$ & \\
\hline $\mathrm{Df}$ & 4 & 4 & & 4 & 4 & & 4 & 4 & \\
\hline $\mathrm{F}$ & 56,497 & - & & 75,599 & - & - & 156,363 & - & - \\
\hline khí-négyzet & - & 167,949 & & - & 250,290 & & - & 464,984 & \\
\hline $\mathrm{P}$ & 0,000 & 0,000 & & 0,000 & 0,000 & & 0,000 & 0,000 & \\
\hline
\end{tabular}

Az egészségi állapot megítélésekor kialakult csoportok FT index szerinti átlagait az 8. táblázat tartalmazza. A különböző egészségi állapotot megjelölők között mind a járási és városi, mind a teljes minta esetén szignifikáns különbség mutatható ki. Az egyes egészségességi kategóriák FTI értékei szinte minden esetben szignifikánsan különböznek egymástól.

\section{Anyagi jólét (Rahmann IV. - NyHP F4)}

A munkahely meglétére vonatkozó kérdésre adott válaszok járási / városi és a teljes mintára vonatkozó eloszlását a 9. táblázat tartalmazza. A városi lakosság nagyobb arányban dolgozik a százalékos adatokat tekintve (54,2\% versus 49,8\%); de az elvégzett khí-négyzet próba szerint ez a különbség nem szignifikáns $\left(\chi^{2}(3, \mathrm{~N}=1631)\right.$ $=3,106, \mathrm{p}=0,078)$. Tehát közel egyenlőarányban $(\mathrm{kb} .50 \%)$ dolgoznak a megkérdezettek a járási és a városi területen.

9. táblázat. A városi és járási lakosok munkahely meglétére vonatkozó kérdésre adott válaszainak eloszlása

\begin{tabular}{|l|c|c|c|}
\hline \multirow{2}{*}{} & \multicolumn{2}{|c|}{ Dolgozik-e Ön jelenleg? } & \multirow{2}{*}{ Összes } \\
\cline { 2 - 3 } & igen & nem & \\
\hline Város - fö & 397 & 336 & 733 \\
\hline \% a városi részmintán belül & $\mathbf{5 4 , 2 \%}$ & $45,8 \%$ & $100,0 \%$ \\
\hline Járás - fö & 447 & 451 & 898 \\
\hline \% a járási részmintán belül & $49,8 \%$ & $\mathbf{5 0 , 2 \%}$ & $100,0 \%$ \\
\hline Teljes minta - fö & 844 & 787 & 1631 \\
\hline \% megoszlás a teljes mintán belül & $51,7 \%$ & $48,3 \%$ & $100,0 \%$ \\
\hline
\end{tabular}

Forrás: Nyíregyháza Életminősége 2015 
A „Dolgozik-e Ön jelenleg?” kérdésre adott válaszok alapján kialakult csoportok FTI értékei mind a városi, mind a járási területen szignifikáns különbséget mutattak (10. táblázat, utolsó sor).

10. táblázat. A munkahely meglétéhez kapcsolódó városi-, járási részmintára és a teljes mintára vonatkozó FT index átlagértékei, rangátlagai és az elemszámok

\begin{tabular}{|c|c|c|c|c|c|c|c|c|c|}
\hline & \multicolumn{3}{|c|}{ Város } & \multicolumn{3}{|c|}{ Járás } & \multicolumn{3}{|c|}{ Összes } \\
\hline $\begin{array}{l}\text { Dolgozik-e } \\
\text { jelenleg? }\end{array}$ & FT átlag & Rangátlag & $\mathrm{N}$ & $\begin{array}{c}\text { FT } \\
\text { átlag }\end{array}$ & Rangátlag & $\mathrm{N}$ & $\begin{array}{c}\text { FT } \\
\text { átlag }\end{array}$ & $\begin{array}{c}\text { Rangátl } \\
\text { ag }\end{array}$ & $\mathrm{N}$ \\
\hline Igen & 7,9886 & 424,22 & 390 & 7,8286 & 550,94 & 439 & 7,9962 & 982,11 & 829 \\
\hline Nem & 5,2876 & 281,22 & 327 & 4,3993 & 340,43 & 449 & 4,6732 & 611,66 & 776 \\
\hline Módszer & $\begin{array}{l}\text { Kétm. t- } \\
\text { próba }\end{array}$ & $\begin{array}{l}\text { Mann- } \\
\text { Whitney }\end{array}$ & & $\begin{array}{l}\text { Kétm. t- } \\
\text { próba }\end{array}$ & $\begin{array}{l}\text { Mann- } \\
\text { Whitney }\end{array}$ & & $\begin{array}{l}\text { Kétm. t- } \\
\text { próba }\end{array}$ & $\begin{array}{c}\text { Mann- } \\
\text { Whitney }\end{array}$ & \\
\hline $\begin{array}{l}\text { Átlagok } \\
\text { különbsége }\end{array}$ & 2,70 & - & - & 3,43 & - & - & 3,32 & - & \\
\hline Df & 715 & - & & 886 & - & & 1603 & - & \\
\hline$t$ & 9,101 & - & & 12,421 & - & & 16,384 & - & \\
\hline $\mathrm{P}$ & 0,000 & 0,000 & & 0,000 & 0,000 & & 0,000 & 0,000 & \\
\hline
\end{tabular}

Forrás: Nyíregyháza Életminösége 2015.

A különböző foglalkozások esetén az előző felmérésekhez hasonlóan, igen változatos képet mutatott az FT index. A városi lakosok között a legmagasabb indexüek voltak a vállalkozók (10,45; 95\% CI [8,65-12,25]; 24 fö), a gazdálkodók (10,37; 95\% CI [7,72-13,03]; 6 fó) és a középszintü vezetők (10,02; 95\% CI [7,61 $12,44] ; 8$ fö). A legalacsonyabb FT index a betanított munkások $(5,37 ; 95 \%$ CI [3,876,87]; 23 fö), felső vezetők (6,17; 95\% CI -[23,04-35,38]; 2 fó) és a szakmunkások (6,58; 95\% CI [5,64-7,54]; 70 fö) voltak. Az egyes szakmák között szignifikáns különbséget mutatott mind az egyszempontos varianciaanalízis ( $\mathrm{df}=16 ; \mathrm{F}=2,758$; $\mathrm{p}=0,000)$, mind a Kruskal-Wallis teszt $(\mathrm{df}=16 ; \mathrm{p}=0,000)$. A járási lakosok körében más arányok figyelhetők meg. A legmagasabb FT átlagérték szintén a vállalkozóké (12,15; 95\% CI [10,07-14,24]; 22 fö); de öket a középszintü vezetők követik (11,72; 95\% CI [7,41-16,03]; 4 fö), majd a felső vezetök (11,30; 95\% CI [6,00-16,60g; 3 fö). A legalacsonyabb átlagértékkel a közvetlen termelésirányítók $(4,14 ; 95 \%$ CI [62,43-70,71]; 2 fó), a segédmunkások $(5,28 ; 95 \%$ CI [4,13-6,42]; 39 fó) és a betanított munkások (6,18;95\% CI [5,31-7,06]; 62 fó) rendelkeztek. Az egyes szakmák között szignifikáns különbséget mutatott mind az egyszempontos varianciaanalízis $(\mathrm{df}=14 ; \mathrm{F}=4,984 ; \mathrm{p}=0,000)$, mind a Kruskal-Wallis teszt $(\mathrm{df}=$ $14 ; \mathrm{p}=0,000)$.

Nyilvánvaló, hogy a fenti adatok értelmezését a válaszadók számának figyelembe vételével kell megtenni. Az alacsony válaszadói szám esetén a konfidenciaintervallumok jelzik a nagyobb szóródást (felső vezetők, stb.), az FT indexek értékeinél ekkor az egyéni sajátosságok sokkal jobban tükröződnek.

A foglalkoztatás módja a járási és városi mintában szignifikáns különbséget mutat $\left(\chi^{2}(5, N=802)=28,399, p=0,000 ;\right.$ Fisher-féle egzakt teszt; $\left.p=0,000\right)-11$. táblázat. 
A folyamatos foglalkoztatás esetén $10 \%$ feletti a különbség a város javára. A második legnagyobb eltérés a közmunka program keretében alkalmazottaknál látható, $6,7 \%$ a járásbeli települések javára.

11. táblázat. A foglalkoztatás módja a városi és járási mintában

\begin{tabular}{|c|c|c|c|c|}
\hline Foglalkoztatás módja & & Város & Járás & Összes \\
\hline \multirow{2}{*}{ Folyamatos, normál foglalkoztatás } & Fő & 290 & 266 & 556 \\
\hline & $\%$ & $74,9 \%$ & $64,1 \%$ & $69,3 \%$ \\
\hline \multirow{2}{*}{ Meghatározott időre szóló szerződéssel } & Fö & 44 & 66 & 110 \\
\hline & $\%$ & $11,4 \%$ & $15,9 \%$ & $13,7 \%$ \\
\hline \multirow{2}{*}{ Részmunkaidőben } & Fö & 22 & 18 & 40 \\
\hline & $\%$ & $5,7 \%$ & $4,3 \%$ & $5,0 \%$ \\
\hline \multirow{2}{*}{ Közmunkaprogram keretében } & Fö & 5 & 33 & 38 \\
\hline & $\%$ & $1,3 \%$ & $8,0 \%$ & $4,7 \%$ \\
\hline \multirow{2}{*}{ Alkalmi munka, szerződéssel } & Fö & 5 & 2 & 7 \\
\hline & $\%$ & $1,3 \%$ & $0,5 \%$ & $0,9 \%$ \\
\hline \multirow{2}{*}{ Egyéb forma } & Fö & 21 & 30 & 51 \\
\hline & $\%$ & $5,4 \%$ & $7,2 \%$ & $6,4 \%$ \\
\hline \multirow{2}{*}{ Összesen } & Fö & 387 & 415 & 802 \\
\hline & $\%$ & $100,0 \%$ & $100,0 \%$ & $100,0 \%$ \\
\hline
\end{tabular}

A kérdőív rákérdezett a havi jövedelemmel való elégedettségre. A válaszadók egy hatfokú skálán jelölhették meg véleményüket. A városi és járási eredményeket a 12 . táblázat mutatja be. A járási és városi lakosok között szignifikáns véleménykülönbség volt kimutatható $\left(\chi^{2}(5, \mathrm{~N}=1624)=106,332, \mathrm{p}=0.000\right)$. A táblázatot a különbség keresése szempontjából áttekintve látható, hogy a városi lakosok nagyobb arányban jelölték meg a kedvezőbb értékelést - három legjobb kategória -, míg a járási lakosok a három kedvezőtlenebb kategóriában jelöltek inkább (lásd a táblázat vastagon szedett részeit).

12. táblázat - A havi jövedelemröl alkotott vélemény a járási és a városi részmintában

\begin{tabular}{|c|c|c|c|c|}
\hline Havi jövedelem, mit mondana & & Város & Járás & Összesen \\
\hline \multirow{2}{*}{$\begin{array}{l}\text { Csak nagy nehézségek árán } \\
\text { jövünk ki belőle }\end{array}$} & fö & 79 & 140 & 219 \\
\hline & $\%$ & $10,8 \%$ & $15,6 \%$ & $13,5 \%$ \\
\hline \multirow{2}{*}{$\begin{array}{l}\text { Nehézségek árán jövünk ki } \\
\text { belöle }\end{array}$} & fö & 87 & 215 & 302 \\
\hline & $\%$ & $11,9 \%$ & $24,0 \%$ & $18,6 \%$ \\
\hline \multirow{2}{*}{$\begin{array}{l}\text { Némi nehézség árán jövünk ki } \\
\text { belöle }\end{array}$} & fö & 191 & 294 & 485 \\
\hline & $\%$ & $26,2 \%$ & $32,8 \%$ & $29,9 \%$ \\
\hline \multirow{2}{*}{ Kijövünk belőle } & fö & 270 & 193 & 463 \\
\hline & $\%$ & $37,0 \%$ & $21,6 \%$ & $28,5 \%$ \\
\hline \multirow{2}{*}{$\begin{array}{l}\text { Viszonylag könnyen kijövünk } \\
\text { belöle }\end{array}$} & fö & 87 & 48 & 135 \\
\hline & $\%$ & $11,9 \%$ & $5,4 \%$ & $8,3 \%$ \\
\hline
\end{tabular}




\begin{tabular}{|l|l|c|c|c|}
\hline \multirow{2}{*}{ Nagyon jól kijövünk belöle } & fö & 15 & 5 & 20 \\
\cline { 2 - 5 } & $\%$ & $\mathbf{2 , 1 \%}$ & $0,6 \%$ & $1,2 \%$ \\
\hline \multirow{2}{*}{ Összesen } & fö & 729 & 895 & 1624 \\
\cline { 2 - 5 } & $\%$ & $100,0 \%$ & $100,0 \%$ & $100,0 \%$ \\
\hline
\end{tabular}

Forrás: Nyíregyháza Életminösége 2015

A teljes mintát elemezve az FT index és a havi jövedelem megítélése tekintetében szignifikáns különbség volt kimutatható (egyszempontos varianciaanalízis, $\mathrm{F}=$ $106,394, \mathrm{df}=5 ; \mathrm{p}=0,000 ;$ Kruskal-Wallis teszt; $\left.\chi^{2}=411,972 ; \mathrm{df}=5 ; \mathrm{p}=0,000\right)$. Az összefüggéseket jól szemlélteti az 4. ábra, ahol a vízszintes tengelyen az egyes jövedelmi elégedettségi kategóriák; a függőleges tengelyen pedig FT indexátlagok vannak jelölve. A 4. ábra mind a teljes minta, mind a járási és városi részminták adatait bemutatja. Egy kivétellel minden esetben szignifikáns eltérés mutatható ki a kategóriák FT indexátlagai között. Az egyetlen kivétel a városi lakosság felső két kategóriája, ahol nem különbözik az FT index átlaga a két csoportban.

4. ábra. Az FT index (függöleges tengely) és a jövedelmi elégedettségi kategóriák (vízszintes tengely). Ábramagyarázat: 1 - csak nagy nehézségek árán jövünk ki belöle; 2 - nehézségek árán jövünk ki belöle; 3 - némi nehézség árán jövünk ki belöle; 4 - kijövünk belöle; 5 - viszonylag könnyen kijövünk belőle; 6 - nagyon jól kijövünk belöle

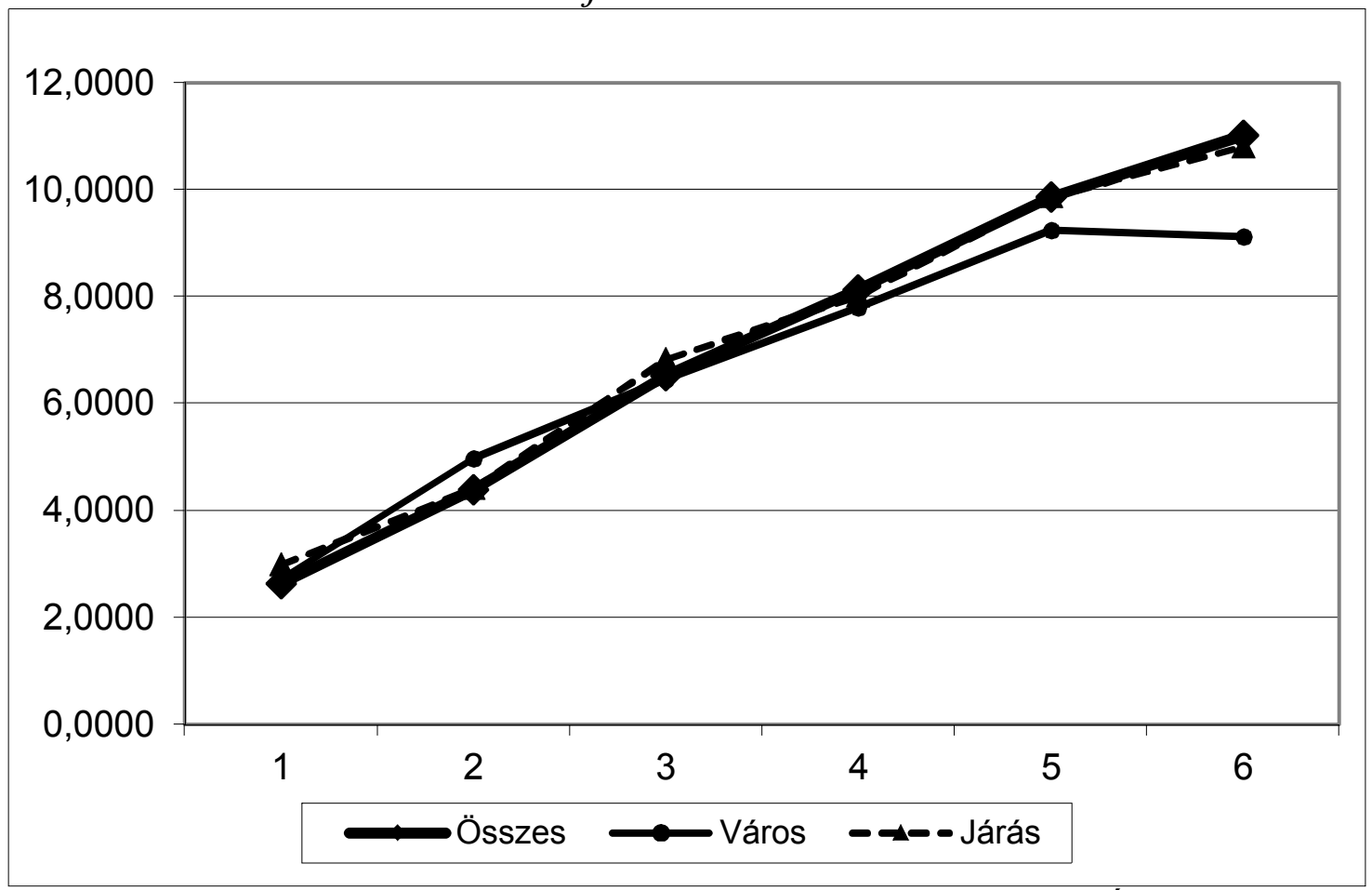

Forrás: Nyíregyháza Életminősége 2015

A városi lakosság körében közel nyolc százalékkal magasabbnak adódott a gépkocsival rendelkező aránya - 13. táblázat. A különbség szignifikáns $\left(\chi^{2}(2, \mathrm{~N}=\right.$ $1615)=12,085, \mathrm{p}=0.002)$. 
13. táblázat. Gépkocsi birtoklása a városi és járási mintában

\begin{tabular}{|l|l|c|c|c|c|}
\hline \multirow{2}{*}{} & \multicolumn{3}{|c|}{ Van-e személygépkocsija? } & \multirow{2}{*}{ Összes } \\
\cline { 3 - 6 } \multicolumn{2}{|c|}{} & Van & $\begin{array}{c}\text { Nincs, nem } \\
\text { engedheti meg }\end{array}$ & \multirow{2}{*}{ Nincs, egyéb ok } & \\
\hline \multirow{2}{*}{ Város } & Fő & 508 & 92 & 123 & 723 \\
\cline { 2 - 6 } & $\%$ & $\mathbf{7 0 , 3 \%}$ & $12,7 \%$ & $17,0 \%$ & $100,0 \%$ \\
\hline \multirow{2}{*}{ Járás } & Fö & 559 & 123 & 210 & 892 \\
\cline { 2 - 6 } & $\%$ & $62,7 \%$ & $\mathbf{1 3 , 8 \%}$ & $\mathbf{2 3 , 5 \%}$ & $100,0 \%$ \\
\hline \multirow{2}{*}{ Összes } & Fö & 1067 & 215 & 333 & 1615 \\
\cline { 2 - 6 } & $\%$ & $66,1 \%$ & $13,3 \%$ & $20,6 \%$ & $100,0 \%$ \\
\hline
\end{tabular}

Forrás: Nyíregyháza Életminösége 2015

Mind a teljes mintában, mind a városi és járási részmintákban a gépkocsival rendelkezők FT életminőség index átlagértéke szignifikánsan magasabb volt, mint a gépkocsival valamilyen okból nem rendelkezők. A különbség egyszempontos varianciaanalízissel (minden esetben $p=0,000$ ) és Kruskal-Wallis teszttel (mindhárom esetben $\mathrm{p}=0,000)$ is kimutatható volt.

\section{Lokális közösség (Rahmann V. - NyHP F6)}

A vallási közösséghez tartozást vizsgálva a városi lakosság körében volt kissé nagyobb (szignifikáns; különbség 4,1\%; $\chi^{2}(1, \mathrm{~N}=1601)=7,369, \mathrm{p}=0.007$; Fisherféle egzakt teszt; p=0,008) a magukat vallási közösséghez sorolók aránya - lásd 14. táblázat.

14. táblázat - Vallási közösséghez való tartozás járási és városi körben

\begin{tabular}{|c|c|c|c|c|}
\hline & \multicolumn{2}{|c|}{ Tagja-e vallási közösségnek? } & \multirow{2}{*}{ Összesen } \\
\hline & & Igen & Nem & \\
\hline \multirow{2}{*}{ Város } & Fö & 90 & 624 & 714 \\
\hline & $\%$ & $12,6 \%$ & $87,4 \%$ & $100,0 \%$ \\
\hline \multirow{2}{*}{ Járás } & Fö & 75 & 812 & 887 \\
\hline & $\%$ & $8,5 \%$ & $91,5 \%$ & $100,0 \%$ \\
\hline \multirow{2}{*}{ Összesen } & Fö & 165 & 1436 & 1601 \\
\hline & $\%$ & $10,3 \%$ & $89,7 \%$ & $100,0 \%$ \\
\hline
\end{tabular}

Forrás: Nyíregyháza Életminősége 2015

Az FT index a teljes minta esetén a magukat vallási körbe sorolók és nem sorolók csoportjában szignifikáns eltérést mutatott. A magukat vallási közösség tagjaiként nem említő válaszadók körében szignifikánsan nagyobbnak mutatkozott az FT index átlagértéke. A két részmintában azonban ettől eltérő helyzet mutatkozott. A járási válaszadók körében az FT index tekintetében nem adódott különbség. A városiak viszont körében igen, de az összképpel szemben a magukat vallási közösségbe sorolók rendelkeztek nagyobb FTI átlagértékkel. A részletes adatok a 15. táblázatban találhatók. 
15. táblázat - A vallási közösséghez való tartozás városi-, járási részmintára és a teljes mintára vonatkozó FT index átlagértékei, rangátlagai és az elemszámok

\begin{tabular}{|c|c|c|c|c|c|c|c|c|c|}
\hline & \multicolumn{3}{|l|}{ Város } & \multicolumn{3}{|l|}{\begin{tabular}{|l|} 
Járás \\
\end{tabular}} & \multicolumn{3}{|l|}{ Összes } \\
\hline $\begin{array}{l}\text { Tagja-e } \\
\text { vallási } \\
\text { közösségnek? }\end{array}$ & $\begin{array}{l}\text { FT } \\
\text { átlag }\end{array}$ & Rangátlag & $\mathrm{N}$ & $\begin{array}{l}\text { FT } \\
\text { átlag }\end{array}$ & Rangátlag & $\mathrm{N}$ & $\begin{array}{l}\text { FT } \\
\text { átlag }\end{array}$ & $\begin{array}{l}\text { Rangátl } \\
\text { ag }\end{array}$ & $\mathrm{N}$ \\
\hline Igen & 9,5263 & 466,15 & 88 & 5,6182 & 408,81 & 74 & 4,6807 & 624,48 & 162 \\
\hline Nem & 6,3497 & 333,27 & 611 & 6,1163 & 443,41 & 806 & 6,5655 & 808,92 & 1417 \\
\hline Módszer & $\begin{array}{l}\text { Kétm. t- } \\
\text { próba }\end{array}$ & $\begin{array}{l}\text { Mann- } \\
\text { Whitney }\end{array}$ & & $\begin{array}{l}\text { Kétm. } \\
\text { t-próba }\end{array}$ & $\begin{array}{l}\text { Mann- } \\
\text { Whitney }\end{array}$ & & $\begin{array}{l}\text { Kétm. } \\
\text { t-próba }\end{array}$ & $\begin{array}{l}\text { Mann- } \\
\text { Whitne } \\
\text { y }\end{array}$ & \\
\hline $\begin{array}{l}\text { Átlagok } \\
\text { különbsége }\end{array}$ & 3,18 & - & - & $-0,50$ & - & & $-1,88$ & - & \\
\hline Df & 697 & - & & 878 & - & & 1577 & - & \\
\hline $\mathrm{t}$ & 6,825 & - & & $-0,797$ & - & & $-5,219$ & - & \\
\hline $\mathrm{P}$ & 0,000 & 0,000 & & 0,428 & 0,262 & & 0,000 & 0,000 & \\
\hline
\end{tabular}

Forrás: Nyíregyháza Életminősége 2015

\section{Munka és aktivitás (Rahmann VI. - NyHP F3)}

A munka világával kapcsolatos elemzések az „Anyagi jólét” alfejezetben már szerepeltek. Itt az egyéb aktivitással kapcsolatos változók közül kettő, az idegen nyelv ismerete és az iskolázottság mutatói kerülnek bemutatásra.

Az idegen nyelvek tekintetében a városiak lényegesen nagyobb arányban jelölték a nyelv ismeretét (16. táblázat; $\left.\chi^{2}(1, N=1636)=47,018, p=0,000\right)$.

16. táblázat. Az idegen nyelv ismerete városiak és járásiak körében

\begin{tabular}{|c|l|c|c|c|}
\hline \multicolumn{2}{|c|}{} & \multicolumn{2}{|c|}{ Rendelkezik-e Ön idegen nyelv ismeretével? } & \multirow{2}{*}{ Összes } \\
\cline { 3 - 5 } \multicolumn{2}{|c|}{} & Igen & Nem & \\
\hline \multirow{2}{*}{ Város } & Fố & 333 & 404 & 737 \\
\cline { 2 - 5 } & $\%$ & $\mathbf{4 5 , 2 \%}$ & $\mathbf{5 4 , 8 \%}$ & $100,0 \%$ \\
\hline \multirow{2}{*}{ Járás } & Fő & 259 & 640 & 899 \\
\cline { 2 - 5 } & $\%$ & $\mathbf{2 8 , 8 \%}$ & $\mathbf{7 1 , 2 \%}$ & $100,0 \%$ \\
\hline \multirow{2}{*}{ Összes } & Fŏ & 592 & 1044 & 1636 \\
\cline { 2 - 5 } & $\%$ & $36,2 \%$ & $63,8 \%$ & $100,0 \%$ \\
\hline
\end{tabular}

Forrás: Nyíregyháza Életminősége 2015

Mind a teljes mintában, mind a városi és járási részmintákban az idegen nyelvet magukénak mondók FT életminőség index átlagértéke szignifikánsan magasabb volt, mint nyelvet nem beszélőké. A különbség egyszempontos varianciaanalízissel (minden esetben $\mathrm{p}=0,000$ ) és Kruskal-Wallis teszttel (mindhárom esetben $\mathrm{p}=0,000$ ) is kimutatható volt.

$\bar{A} z$ iskolai végzettség vonatkozásában különbség adódott a városi és járási lakosok között $\left(\chi^{2}(1, \mathrm{~N}=1615)=157,210, \mathrm{p}=0,000\right)$. Részleteket lásd a 17. táblázatban. A városi válaszadók között lényegesen nagyobb a közép- és felsőfokú végzettségủek 
aránya. A járási lakosságra a nyolc általános és a szakmunkásképző az inkább jellemző végzettség.

17. táblázat. A legmagasabb iskolai végzettség arányai a járási és városi mintában. (Ábramagyarázat: 1.8 általános alatt; 2.8 általános; 3. szakmunkásképző; 4. szakközépiskolai érettségi; 5. gimnáziumi érettségi; 6. érettségi után szakképzés, technikum; 7. föiskola, alapképzés; 8. egyetem mesterképzés; 9. doktori fokozat)

\begin{tabular}{|l|c|c|c|c|c|c|c|c|c|c|}
\hline & \multicolumn{7}{|c|}{ legmagasabb iskolai végzettsége } & \multirow{2}{*}{ Össz. } \\
\cline { 2 - 11 } & 1 & 2 & 3 & 4 & 5 & 6 & 7 & 8 & 9 & \\
\hline Város fö & 19 & 61 & 151 & 102 & 110 & 82 & 142 & 52 & 5 & 724 \\
\hline Város \% & $2,6 \%$ & $8,4 \%$ & $\mathbf{2 0 , 9 \%}$ & $\mathbf{1 4 , 1 \%}$ & $\mathbf{1 5 , 2 \%}$ & $11,3 \%$ & $\mathbf{1 9 , 6 \%}$ & $7,2 \%$ & $0,7 \%$ & $100,0 \%$ \\
\hline Járás fö & 40 & 200 & 292 & 97 & 103 & 62 & 84 & 13 & 0 & 891 \\
\hline Járás \% & $4,5 \%$ & $\mathbf{2 2 , 4 \%}$ & $\mathbf{3 2 , 8 \%}$ & $10,9 \%$ & $\mathbf{1 1 , 6 \%}$ & $7,0 \%$ & $9,4 \%$ & $1,5 \%$ & $0,0 \%$ & $100,0 \%$ \\
\hline Össz. & 59 & 261 & 443 & 199 & 213 & 144 & 226 & 65 & 5 & 1615 \\
\hline$\%$ & $3,7 \%$ & $16,2 \%$ & $27,4 \%$ & $12,3 \%$ & $13,2 \%$ & $8,9 \%$ & $14,0 \%$ & $4,0 \%$ & $0,3 \%$ & $100,0 \%$ \\
\hline
\end{tabular}

Forrás: Nyíregyháza Életminösége 2015

Mind a teljes mintában, mind a városi és járási részmintákban a növekvő iskolai végzettség nagyobb FT életminőség index átlagértéket jelentett. A különbség egyszempontos varianciaanalízissel (minden esetben $\mathrm{p}=0,000$ ) és Kruskal-Wallis teszttel (mindhárom esetben $\mathrm{p}=0,000$ ) is kimutatható volt.

\section{Személyes biztonság (Rahmann VII. - NyHP F7)}

A környezeti személyes biztonságot, a vandalizmust és bünözést a városi lakosok 10,8\%-a, a járásiak 7,1\%-a jelölte problémának. Ez a 3,7\%-os különbség szignifikáns a számítások szerint $\left(\chi^{2}(1, \mathrm{~N}=1591)=6,696, \mathrm{p}=0,010 ; 18\right.$. táblázat $)$.

18. táblázat. Vandalizmus, bünözés a személyes környezetben - városi és járási adatok

\begin{tabular}{|l|l|c|c|c|}
\hline \multirow{2}{*}{ város } & & \multicolumn{2}{|c|}{ vandalizmus, bünözés } & \multirow{2}{*}{ Összes } \\
\cline { 3 - 4 } & Fö & igen & nem & 78 \\
\cline { 2 - 4 } & $\%$ & $\mathbf{1 0 , 8 \%}$ & 843 & 721 \\
\hline \multirow{2}{*}{ járás } & Fö & 62 & 808 & $100,0 \%$ \\
\cline { 2 - 4 } & $\%$ & $7,1 \%$ & $\mathbf{9 2 , 9 \%}$ & $100,0 \%$ \\
\hline \multirow{2}{*}{ Összes } & Fö & 140 & 1451 & 1591 \\
\cline { 2 - 4 } & $\%$ & $8,8 \%$ & $91,2 \%$ & $100,0 \%$ \\
\hline
\end{tabular}

Forrás: Nyíregyháza Életminősége 2015

Mind a teljes mintában, mind a városi és járási részmintákban a rossz személyes biztonságot jelzők lényegesen kisebb FTI átlagértéket mutattak. A részletes számítások a 19. táblázatban láthatók. 
19. táblázat - A környezet biztonsága és a városi-, járási részmintára és a teljes mintára vonatkozó FT index átlagértékei, rangátlagai és az elemszámok

\begin{tabular}{|c|c|c|c|c|c|c|c|c|c|}
\hline & \multicolumn{3}{|c|}{ Város } & \multicolumn{3}{|c|}{ Járás } & \multicolumn{3}{|c|}{ Összes } \\
\hline $\begin{array}{l}\text { Vandaliz- } \\
\text { mus, bünö- } \\
\text { zés a kör- } \\
\text { nyezetben? }\end{array}$ & FT átlag & Rangátlag & $\mathrm{N}$ & FT átlag & Rangátlag & $\mathrm{N}$ & FT átlag & $\begin{array}{l}\text { Rang- } \\
\text { átlag }\end{array}$ & $\mathrm{N}$ \\
\hline Igen & 4,4472 & 236,23 & 77 & 2,9654 & 263,18 & 62 & 2,8372 & 444,12 & 139 \\
\hline Nem & 7,0502 & 366,24 & 626 & 6,3206 & 446,63 & 804 & 6,7370 & 818,13 & $\begin{array}{c}143 \\
0\end{array}$ \\
\hline Módszer & $\begin{array}{l}\text { Kétm. t- } \\
\text { próba }\end{array}$ & $\begin{array}{c}\text { Mann- } \\
\text { Whitney }\end{array}$ & & $\begin{array}{l}\text { Kétm. t- } \\
\text { próba }\end{array}$ & $\begin{array}{l}\text { Mann- } \\
\text { Whitney }\end{array}$ & & $\begin{array}{l}\text { Kétm. t- } \\
\text { próba }\end{array}$ & $\begin{array}{l}\text { Mann- } \\
\text { Whitne } \\
\text { y }\end{array}$ & \\
\hline $\begin{array}{l}\text { Átlagok } \\
\text { különbsége }\end{array}$ & $-2,60$ & - & - & $-3,36$ & - & - & $-1,88$ & - & - \\
\hline $\mathrm{Df}$ & 701 & - & & 864 & - & & 1567 & - & \\
\hline $\mathrm{t}$ & $-5,259$ & - & & $-4,523$ & - & & $-8,951$ & - & \\
\hline $\mathrm{P}$ & 0,000 & 0,000 & & 0,000 & 0,000 & & 0,000 & 0,000 & \\
\hline
\end{tabular}

\section{Környezet minősége (Rahmann VIII. - NyHP F5)}

Az emberi környezet egy fontos eleme a lakás / lakhatás, amelynek súlyosabb hibájára is rákérdezett a kérdőív. A városi minta nagyobb arányban jelezte, hogy életvitelt nehezítő hiba van lakásában, de ez a járási aránnyal összevetve nem jelentett szignifikáns különbséget $\left(\chi^{2}(1, \mathrm{~N}=1616)=3,821, \mathrm{p}=0,051 ; 20\right.$. táblázat).

Az FT index tekintetében ismét szignifikáns eltérések voltak megfigyelhetők (21. táblázat). Minden szinten azok mutattak nagyobb FTI életminőség átlagot, akik a hibával nem rendelkező lakásokban laktak.

20. táblázat. A lakás életvitelt nehezitö hibája.

Járási és városi arányok a mintában

\begin{tabular}{|l|l|c|c|c|}
\hline \multirow{2}{*}{} & & \multicolumn{2}{|c|}{$\begin{array}{c}\text { Van-e a lakásnak olyan hibája, ami } \\
\text { a napi életvitelt nehezíti? }\end{array}$} & \multirow{2}{*}{ Összes } \\
\cline { 3 - 5 } & & Van & Nincs & \\
\hline \multirow{2}{*}{ Város } & Fő & 111 & 606 & 717 \\
\cline { 2 - 5 } & $\%$ & $15,5 \%$ & $84,5 \%$ & $100,0 \%$ \\
\hline \multirow{2}{*}{ Járás } & Fő & 109 & 790 & 899 \\
\cline { 2 - 5 } & $\%$ & $12,1 \%$ & $87,9 \%$ & $100,0 \%$ \\
\hline \multirow{2}{*}{ Összes } & Fö & 220 & 1396 & 1616 \\
\cline { 2 - 5 } & $\%$ & $13,6 \%$ & $86,4 \%$ & $100,0 \%$ \\
\hline
\end{tabular}

Forrás: Nyíregyháza Életminösége 2015 
21. táblázat. A lakás hibájára vonatkozó különbségek és az FT index

\begin{tabular}{|c|c|c|c|c|c|c|c|c|c|}
\hline & Város & & & Járás & & & Összes & & \\
\hline $\begin{array}{ll}\text { Van-e } & \text { a } \\
\text { lakásnak } & \\
\text { hibája? } & \end{array}$ & FT átlag & $\begin{array}{l}\text { Rang- } \\
\text { átlag }\end{array}$ & $\mathrm{N}$ & $\begin{array}{l}\text { FT } \\
\text { átlag }\end{array}$ & $\begin{array}{l}\text { Rang- } \\
\text { átlag }\end{array}$ & $\mathrm{N}$ & $\begin{array}{l}\text { FT } \\
\text { átlag }\end{array}$ & $\begin{array}{l}\text { Rang- } \\
\text { átlag }\end{array}$ & $\mathrm{N}$ \\
\hline Van & 4,9471 & 259,89 & 109 & 4,9540 & 366,83 & 107 & 4,8148 & 622,31 & 216 \\
\hline Nincs & 7,0872 & 367,78 & 592 & 6,2437 & 455,70 & 782 & 6,6098 & 822,73 & 1374 \\
\hline Módszer & $\begin{array}{l}\text { Kétm. t- } \\
\text { próba }\end{array}$ & $\begin{array}{l}\text { Mann- } \\
\text { Whitney }\end{array}$ & \multirow{5}{*}{ - } & $\begin{array}{l}\text { Kétm. } \\
\text { t-próba }\end{array}$ & $\begin{array}{l}\text { Mann- } \\
\text { Whitney }\end{array}$ & & $\begin{array}{l}\text { Kétm. t- } \\
\text { próba }\end{array}$ & $\begin{array}{l}\text { Mann- } \\
\text { Whitney }\end{array}$ & \multirow{5}{*}{ - } \\
\hline $\begin{array}{l}\text { Átlagok } \\
\text { különbsége }\end{array}$ & $-2,14$ & - & & $-1,29$ & - & & $-1,80$ & - & \\
\hline Df & 699 & - & & 887 & - & & 1588 & - & \\
\hline $\mathrm{t}$ & $-5,943$ & - & & $-2,448$ & - & & $-5,660$ & - & \\
\hline $\mathrm{P}$ & 0,000 & 0,000 & & 0,016 & 0,001 & & 0,000 & 0,000 & \\
\hline
\end{tabular}

Forrás: Nyíregyháza Eletminösége 2015

\section{Érzelmi jólét (Oxdord Boldogságkérdőív - Rahmann II. - NyHP F8)}

Az eddigi eredmények sora azon eredményeket követik, amelyek az előző hullámokban is fontos szerepet játszottak az FT életminőség index tulajdonságainak kutatása során. Az új kérdéscsoport, az Oxford Boldogságkérdőívvel kapcsolatos fontosabb eredmények a következők.

Az összesített / aggregált Boldogságváltozó eloszlását az 5. ábrán lévő grafikon szemlélteti. Az ábrán látható folytonos vonal / haranggörbe az adatokhoz illesztett normális eloszlást szemlélteti. Ehhez a görbéhez hasonlítva az adatokból alkotott hisztogramból elmondható, hogy a hisztogram egy kicsit jobbra tolódik, a szimmetria kissé sérül (válaszadók száma: 1349 fö; hiányzó válaszok száma: 314 fö; átlag: 4,22; 95 \% CI az átlagra: [4,18 - 4,26]; 5\%-os vágott átlag: 4,25; Std. Error 0,020; szórás: 0,734; minimum: 1,28; maximum: 5,86; csúcsosság / skewness: 0,421; lapultság / kurtosis: 0,062). A normalitásvizsgálatok elvetették a változó eloszlásának normalitását (Kolmogorov-Smirnov; Shapiro-Wilk; mindkét esetben p $=0,000)$.

5. ábra. Az Oxford Boldogság skála eloszlása a mintában

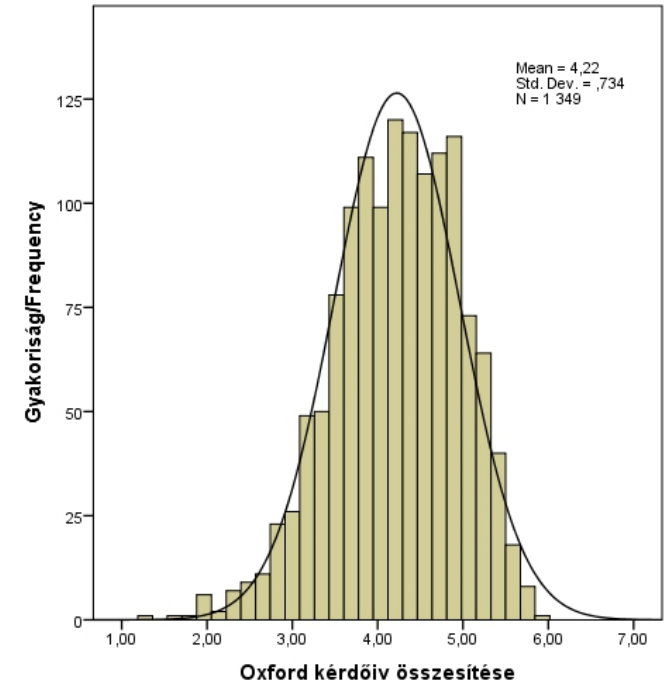

Forrás: Nyíregyháza Életminősége 2015 
A városi és járási adatokat összevetve szignifikáns különbség adódott az Oxford skála tekintetében (kétmintás t-próba; $\mathrm{t}=3,681$; $\mathrm{df}=1347 ; \mathrm{p}=0,000$; az átlagok közötti különbség $=0,15$; Mann-Whitney teszt; $p=0,000)$. A városi lakosok Oxford átlagértéke $(4,31)$ adódott nagyobbnak a járási lakosokénál $(4,16)$.

Az Oxford Boldogságérték és a teljes mintára számított FT index közötti Pearsonféle korrelációs együttható gyenge, de szignifikáns kapcsolatot mutat $(\mathrm{r}=0,372 ; 0,01$ szinten szignifikáns).

A 29 kérdés összevonhatóságát tesztelő lineáris modell függő változója a saját érzelmi állapotot vizsgáló kérdés, független változói pedig a Boldogságkérdőív 29 kérdése volt. A lineáris modell Pearson-féle korrelációs- és determinációs együtthatója közepes értéket mutatott $\left(r=0,687 ; r^{2}=0,472\right.$; a becslés standard hibája 0,472). Az egyszempotnos varianciaanalízis a kapcsolat meglétét igazolta $(\mathrm{F}=$ $38,789 ; \mathrm{df}=29 ; \mathrm{p}=0,000)$. A regressziós modell együtthatói a 22. táblázatban láthatók. Az elemzésben a 3., 6., 9., 15., 28. és 29. kérdések voltak mérvadók.

\section{2. táblázat. Az érzelmi állapotra vonatkozó lineáris modell együtthatói} $A+$ jel a mérvadó $R S T$ változókat jelöli

\begin{tabular}{|c|c|c|c|c|c|}
\hline & \multicolumn{2}{|c|}{$\begin{array}{l}\text { Nem standardizált } \\
\text { együtthatók }\end{array}$} & \multirow{2}{*}{\begin{tabular}{|c|}
$\begin{array}{c}\text { Std. } \\
\text { Egyh. }\end{array}$ \\
Beta
\end{tabular}} & \multirow[b]{2}{*}{$\mathrm{t}$} & \multirow[b]{2}{*}{ Sig. } \\
\hline & $\mathrm{B}$ & Std. Err. & & & \\
\hline (Constant) & 2,791 & ,206 & & 13,575 &, 000 \\
\hline+1. nem örül amilyen &, 005 & 017 &, 006 & ,271 &, 786 \\
\hline +2. rendkívüli módon érdekli mások & 024 & 017 & 031 & 1,421 &, 155 \\
\hline +3. úgy érzi nagyon jó élni &, 135 &, 029 &, 147 & 4,744 &, 000 \\
\hline 4. pozitív mindenki felé &,- 008 & 026 &,- 008 &,- 306 &, 760 \\
\hline 5. ritkán ébred kipihenten &,- 023 & 017 &,- 031 & $-1,365$ &, 173 \\
\hline +6. nem optimista &,- 057 & 019 &,- 079 & $-3,013$ &, 003 \\
\hline +7. dolgokat szórakoztatónak tartja &, 016 & 021 &, 019 &, 783 &, 434 \\
\hline+8 . belemerül amit csinál, elkötelezett &,- 036 &, 025 &,- 038 & $-1,478$ & 140 \\
\hline 9. szép az élet &, 066 &, 029 &, 072 & 2,251 &, 025 \\
\hline+10 . nem valami jó ez a világ &, 016 &, 020 &, 020 & ,804 &, 422 \\
\hline 11. sokat nevet & 041 & 026 &, 047 & 1,584 &, 113 \\
\hline+12 . szinte mindennel elégedett &, 044 &, 025 & 051 & 1,785 & 074 \\
\hline 13. hiszi, hogy nem vonzó &, 004 & 018 &, 005 & 202 & 840 \\
\hline 14. különbség amit szeretne és amit tett &,- 004 & 019 &,- 005 &,- 189 &, 850 \\
\hline 15. nagyon boldog &, 257 & 029 & ,293 & 8,724 &, 000 \\
\hline 16. dolgokban megtalálja a szépséget &,- 001 &, 031 &,- 001 &,- 020 & ,984 \\
\hline 17. képes felvidítani a többieket &, 048 & 028 &, 051 & 1,717 &, 086 \\
\hline 18. amire akar tud időt szakítani &,- 029 &, 025 &,- 029 & $-1,150$ &, 250 \\
\hline 19. úgy érzi nincs hatással az élete alakulására &,- 014 &, 020 &,- 019 &,- 738 &, 461 \\
\hline $\begin{array}{l}\text { 20. képesnek érzi magát, hogy bármit } \\
\text { elvállaljon }\end{array}$ &, 005 & ,022 & ,006 & ,246 & ,806 \\
\hline 21. szellemileg teljesen éber & 018 &, 025 & ,021 &, 720 & 471 \\
\hline 22. gyakran örül &, 002 &, 026 &, 002 &, 073 & ,942 \\
\hline+23 . nehezen hoz döntéseket &,- 016 &, 017 &,- 021 &,- 905 &, 366 \\
\hline $\begin{array}{l}\text { 24. nem érzi igazán értelmesnek, céllal telinek } \\
\text { az életét }\end{array}$ &,- 031 &, 023 &,- 037 & $-1,348$ & ,178 \\
\hline
\end{tabular}




\begin{tabular}{|l|r|r|r|r|r|}
\hline +25. rengeteg energiája van &, 018 &, 023 &, 022 &, 782 &, 434 \\
\hline 26. pozitívan befolyásolja a történéseket &,- 039 &, 026 &,- 042 & $-1,532$ &, 126 \\
\hline 27. nem érzi jól magát másokkal &,- 029 &, 025 &,- 032 & $-1,181$ &, 238 \\
\hline +28. nem érzi egészségesnek magát &,- 054 &, 018 &,- 076 & $-3,000$ & $\mathbf{, 0 0 3}$ \\
\hline 29. nincsenek vidám emlékei &,- 080 &, 025 &,- 084 & $-3,148$ & $\mathbf{, 0 0 2}$ \\
\hline \multicolumn{7}{|c|}{ Forrás: Nyíregyháza Eletminösége 2015 } \\
\hline
\end{tabular}

Ugyanezeket a változókat az RST modellbe bevonva, 11 kérdés bizonyult mérvadónak az érzelmi állapot vonatkozásában (1., 2., 3., 6., 7., 8., 10., 12., 23., 25., 28.). A két modellben három közös változó szerepel: a 3., 6. és 28 . változók.

\section{Összegzés}

Az életminőség vizsgálatok összefoglalásaként elmondható, hogy a korábbi felmérésekkel egyező eredmények adódtak 2015-ben is. Újdonságot jelent a járási és városi adatok összehasonlítása. A részletek a következők.

- Az index belső paraméterei kis mértékben változtak az előző évekhez képest. Az FT index átlagai szintén kis ingadozást mutattak. A kapcsolódó konfidencia-intervallumok szinte minden esetben átfedik egymást, az életminőség átlagok időbeli változása kismértékü.

- A járási és városi mintában a férfi-nő arány nem különbözött. A teljes minta és a járási alminta esetén a korábbi felmérésekhez hasonló a tendencia, a férfiak nagyobb FT index-átlagértékei voltak megfigyelhetők. A városi adatok esetén azonban ez a különbség ebben a hullámban nem volt szignifikáns. Az átlagok ebben az esetben is a férfiak csoportjában mutatott nagyobb FTI értéket. Tovább vizsgálható, hogy melyek azok a paraméterek, amelyekben a férfiak és nők között különbség mutatkozik.

- Az FT index átlagértéke a járási lakosok körében szignifikánsan alacsonyabb értéket mutatott. Ez magyarázható azzal, hogy Nyíregyháza sok tekintetben (munkahely, kultúra, egészségügyi ellátás, stb.) a megye tényleges központja. A Nyíregyházára vonatkozó gazdasági mutatók (Gini együttható, Hoover index, Éltető index) nagyon hasonlóak voltak az országos adatokhoz (Fábián, Takács, 2012), (Fábián, Takács, Szigeti, 2014). Az itt élők tapasztalata szerint Nyíregyháza környező települései kevésbé fejlettek. Ez részben tükröződik az FT index átlagértékeiben is. Az elemzés lehetővé tette a települések szerinti különbségek kimutatását. Ezek szerint Nyírpazony és Sényő az FT index szerint a legmagasabb átlagértékü, másik négy település (Napkor, Nyírtelek, Kótaj, Újfehértó) pedig az átlagostól jobban lemarad. A szignifikánsan alacsonyabb FTI átlagértékü települések esetében érdemes tovább kutatni azokat a jellemzőket, amelyek érdemben változtathatnának a helyzeten.

- A vizsgálatok a városi és járási lakosok között családi állapot szerinti megoszlás tekintetében nem mutattak különbséget. Különbség adódott viszont az FT indexet tekintve. Az előző vizsgálatokhoz hasonlóan, a társsal élők tekinthetők boldogabbnak, elégedettebbeknek. 
- Az egészségi állapot vonatkozásában járási és városi szinten szignifikáns különbségek mutatkoztak. A városi lakosság ítélte meg kedvezőbben egészségi állapotát. Ennek közvetett magyarázata lehet az egészségügyi ellátás elérhetőségében (utazási többlet) rejlő különbségek okozta pszichés hatás. 2015-ös mintán is igaz, hogy az egészségi állapot szerint a magukat jobb egészségi állapotúnak vallók nagyobb index-értékkel rendelkeznek (gazdasági aktivitás, iskolai végzettség, jövedelem, stb. tekintetében).

- A járási és városi részminta foglalkoztatása azonos szintünek tekinthető. A munkával rendelkezők FTI értékei minden esetben szignifikánsan magasabbnak mutatkoztak. A munka/munkahely megléte növelte az indexet. A foglalkozások eloszlása, az egyes foglalkozási típusok FTI indexátlagai és a foglalkoztatás módja a két részmintában szignifikánsan különbözőnek adódott. A különböző foglalkozások esetén a magasabb iskolai végzettség nagyobb indexértéket jelent. A tulajdonosi / alkalmazotti státusz az indexértékben is különbözik a tulajdonosi kör javára. Kiemelhető a városiak körében a folyamatos normál munkavégzés erőssége; a járási körben pedig a közmunkaprogram szerepe.

- Elégedettebbnek mondhatók a nyíregyháziak a járási lakosokkal szemben a fizetés tekintetében is. Ez jelezheti közvetlenül a fizetés nagyságával való elégedettséget, de közvetett jelzést is adhat a munkába járás körülményei, az utazási feltételek, a munkakörülmények, stb. vonatkozásában is.

- A különböző gazdasági „,rétegek” (szegények, alsó középréteg, középréteg, felső középréteg, jómódúak) között szintén kimutatható a különbség. A gazdasági tőke növekedésével növekszik az index-érték. A magukat felsőbb gazdasági rétegbe sorolók indexértéke is magasabb.

- A városi lakosság inkább megengedheti egy gépkocsi fenntartásával járó költségeket. Továbbra is magasabbnak adódott a gépkocsival rendelkezők életminőség indexe.

- A vallási közösséghez való tartozás a korábbi évekhez hasonlóan ellentmondásos képet mutat. Meglepő, de a városi lakosság körében adódott magasabb vallási közösséghez való tartozás. Az FT index tekintetében az átlagok nagyságrendi sorrendje a teljes és a két részminta esetén éppen fordított. Ilyen látszólagos ellentmondás a belső szerkezet feltárásával magyarázható. A korcsoportos eloszlások további tanulmányozása magyarázatot adhat ebben a kérdésben.

- A járási és városi részminta nyelvismerete különböző. A városi kör nagyobb arányban jelezte a nyelvismerete meglétét. Ismét igazolódott, hogy a nyelvismeret nagyobb életminőség index értékkel párosul.

- A városiak körében a magasabb iskolai végzettségüek aránya magasabb. Újra igazolódott az, hogy a magasabb iskolázottsághoz magasabb indexérték társul.

- A vandalizmusra, bünözésre vonatkozó kérdés a városi körben mutatott kismértékü, de szignifikánsan magasabb arányokat. A vártnak megfelelően a békésebb környezet magasabb életminőség indexet mutat. 
Az Oxford Boldogságkérdőív körében végzett elemzések rámutattak a sorrendi skálák alkalmazásának korlátaira - az összevonásban, az átlagképzésben rejlő ellentmondásra. A sorrendi típusú változóra (érzelmi állapot) vonatkozó lineáris regressziós elemzés 6 kérdést emelt ki, mint magyarázó változót. Az RST módszere 11 változót, amely csak három esetben egyezett meg a lineáris regressziós vizsgálat eredményével. Mindkét módszer alapvető célja a változószám redukálása - amit láthatóan eltérő eredménnyel tesznek meg. Az életminőség index továbbfejlesztése szempontjából a megfelelő redukáló módszer kiválasztása fontos tényező.

Az életminőség modell jelenlegi állapotában tehát még nem tekinthető véglegesnek. A kutatómunka célja olyan összetett index kialakítása, amely alkalmas a sokféle nézőpontokból eredő különbségek kimutatására. A legalapvetőbb összehasonlítások a területi- és időbeli viszonyok elemzése; ezek már a korábbi kutatásokban is megjelentek. Ezen túl az index a különbözö társadalmi rétegek közötti különbségek elemzésére is módot adhat - megalapozottabb döntések meghozatalát teheti lehetővé gazdasági és politikai szinteken. Az elvégzendő további kutatómunka egyik iránya az Oxford Boldogságkérdőív modellbe illesztése. Ezen eredmények várhatóan tapasztalatot nyújtanak a többi sorrendi változó összevonásának kérdésében is. További feladat a modell pontosítása, az eredmények összevetése érdekében normalizáló eljárás alkalmazása, az index százalékos formában történő megjelenítése az interpretálhatóság könnyítése érdekében.

\section{Felhasznált Irodalom}

1. Balogh E., Fábián G. (2012): Támogató rendszerek, szociális problémák és segélyezés. In: Fábián Gergely, Patyán László, Huszti Éva (szerk.) Életminőség Nyíregyházán. Nyíregyháza: Debreceni Egyetem Egészségügyi Főiskolai Kar, pp. 135-154.

2. Balogh E., R. Fedor A. (2014): Segélyezés és támogató rendszerek. Acta Medicinae et Sociologica, Vol. 5. No 12-13. Nyíregyháza.

3. Z. E. Csajbók (2013): Approximation of Sets Based on Partial Covering. Transactions on Rough Sets XVI. Volume 7736 of the series Lecture Notes in Computer Sci-ence pp 144220.

4. Ethical Markets quality of life indicators (2000) - EMQLI. http://ethicalmarketsqualityoflife.com/ Utolsó letöltés: 2015.09.19.

5. Erdei R., R. Fedor A., Berencsiné Madácsi E. (2014): A nyíregyházi lakosok szubjektív egészségi állapota és annak változásai. Acta Medicinae et Sociologica, Vol. 5. No 12-13. Nyíregyháza.

6. Fábián G., Takács P. (2012): A jövedelmi egyenlőtlenségek változásai és a szegénység. In: Fábián Gergely, Patyán László, Huszti Éva (szerk.) Életminőség Nyíregyházán. Nyíregyháza: Debreceni Egyetem Egészségügyi Főiskolai Kar, pp. 33-48.

7. Fábián G., Takács P., Szigeti F. (2014): A jövedelmi helyzet változása, a társadalmi polarizálódás jellemzői Nyíregyháza városában. Acta Medicinae et Sociologica, Vol. 5. No 12-13. Nyíregyháza.

8. Fábián G., Takács P., Szigeti F. (2015): Jövedelmi helyzet és jövedelmi szegénység. Acta Medicinae et Sociologica Vol. 6. No. 18-19: 68-79. 
9. P. Hills, M. Argyle (2002): The Oxford Happiness Questionnaire: A compact scale for the measurement of psychological well-being. Personality and Individual Differences, Vol 33(7), Nov 2002, 1071-1082.

10. Huszti É. (2012): Társas kapcsolatok. Családi, rokoni, baráti kapcsolatok Nyíregyháza lakói körében, 2008-2010. In: Fábián Gergely, Patyán László, Huszti Éva (szerk.) Elet-minőség Nyíregyházán. Nyíregyháza: Debreceni Egyetem Egészségügyi Főiskolai Kar, pp. 155-176.

11. Huszti É. (2014): Társas kapcsolatok Nyíregyházán. Acta Medicinae et Sociologica, Vol. 5. No 12-13. Nyíregyháza.

12. Huszti É. (2015): Mondd meg, kikkel töltöd az idődet, s megmondom, ki vagy. A társas támogatást nyújtó személyes kapcsolati háló néhány jellemzője és müködése a Nyíregyházi járásban. Acta Medicinae et Sociologica Vol. 6. No. 18-19, 121-144.

13. Hüse L. (2015): A szubjektív egészségi állapot tényezői és azok változása Nyíregyházán és vonzáskörzetében. Acta Medicinae et Sociologica Vol. 6. No. 18-19: 96-120.

14. Jóna Gy., Jávorné Erdei R. (2012): A szubjektív egészségi állapot meghatározó tényezői Nyíregyházán. In: Fábián Gergely, Patyán László, Huszti Éva (szerk.) Életmi-nőség Nyíregyházán. Nyíregyháza: Debreceni Egyetem Egészségügyi Főiskolai Kar, pp. 99-116.

15. Kárpáti J. (2014): Az életminőségről népszerü formában. Statisztikai Szemle, 2014.02. p. 139-158.

16. Kovács Balázs, Horkay Nándor, dr. Michalkó Gábor (2006): A turizmussal összefüggő életminőség-index kidolgozásának alapjai. Turizmus Bulletin. X. 2.

http://itthon.hu/site/upload/mtrt/

Turizmus_Bulletin/bulletin_2006_2/

eletminoseg_index.html Utolsó letöltés: 2015.09.19.

17. Kovács Balázs (2007): Életminőség - boldogság - turizmusstratégia. Polgári Szemle, 2007. február. Hivatkozás: Sebestyén T. 2005b: Életminőség és boldogság vizsgálatok magyar trendje globális összehasonlításban. Eutrend Kutató. Budapest. (Kézirat)

18. Krizsai A., Tóthné Csatlós I. (2015): Szociális problémák és a segélyezési rendszer átalakulása a Nyíregyházi járás településein. Acta Medicinae et Sociologica Vol. 6. No. 1819: 181-197.

19. Malakucziné Póka M. (2015): A Nyíregyházi járás települési szerkezeti, demográfiai, háztartási jellemzői. Acta Medicinae et Sociologica Vol. 6. No. 18-19: 11-29.

20. Patyán L. (2012): Időskorúak életminősége. In: Fábián Gergely, Patyán László, Huszti Éva (szerk.) Életminőség Nyíregyházán. Nyíregyháza: Debreceni Egyetem Egészségügyi Föiskolai Kar, pp. 117-134.

21. Patyán L. (2015): A Nyíregyházi járásban élő idősek életkörülményei. Acta Medicinae et Sociologica Vol. 6. No. 18-19: 162-180.

22. Z. Pawlak (1982): Rough sets. International Journal of Computer \& Information Sciences. October 1982, Volume 11, Issue 5, pp 341-356.

23. R. Fedor A. (2012): A gazdasági aktivitás lokális jellemzői. Nők és férfiak a „munka piacán”. In: Fábián Gergely, Patyán László, Huszti Éva (szerk.) Életminőség Nyíregyházán. Nyíregyháza: Debreceni Egyetem Egészségügyi Főiskolai Kar, pp. 83-98.

24. R. Fedor A., Jávorné Erdei R. (2014): A foglalkoztatás jellemzői Nyíregyházán. Acta Medicinae et Sociologica, Vol. 5. No 12-13. Nyíregyháza.

25. R. Fedor A., Balogh E.: A foglalkoztatás és a munkanélküliség jellemzői a Nyíregyházi járásban. Acta Medicinae et Sociologica Vol. 6. No. 18-19: 47-67.

26. T. Rahman, R. C. Mittelhammer, P. Wandschneider (2005): Measuring the Quality of Life across Countries: A Sensitivity Analysis of Well-being Indices. Working Paper Series RP 2005/06, World Institute for Development Economic Research (UNU-WIDER).

27. L. S. Riza, A. Janusz, C. Bergmeir, C. Cornelis, F. Herrera, D. Śle zak, J. M. Benítez (2014): Implementing algorithms of rough set theory and fuzzy rough set theory in the R package „RoughSets”. Information Sciences, V.287. pp. 68-89.

28. J. M. Stiglitz, A. Sen, J.-P. Fitoussi (2009): Report by the commission on the measurement of economic performance and social progress. http://www.stiglitz-sen-fitoussi.fr/ documents/ rapport_anglais.pdf; Utolsó letöltés: 2015.09.19. 
29. Szigeti F., Fábián G., Takács P. (2015): Az érzelmi jóllét mérése a Nyíregyházi járás településein. Acta Medicinae et Sociologica Vol. 6. No. 18-19: 145-161.

30. Szilicsány É. P. (2014): Az anyagi depriváció jelenléte Nyíregyházán, 2012-ben. Acta Medicinae et Sociologica, Vol. 5. No 12-13. Nyíregyháza.

31. Szilicsány É. P. (2015): Megélhetési nehézségek és nélkülözés a Nyíregyházi járásban és Szoboszlai Katalin: Lakásjellemzők a Nyíregyházi járásban és a megyeszékhelyen. Acta Medicinae et Sociologica Vol. 6. No. 18-19: 80-95.

32. Szoboszlai K. (2012): Lakásjellemzők Nyíregyházán 2008-2010. In: Fábián Gergely, Patyán László, Huszti Éva (szerk.) Életminőség Nyíregyházán. Nyíregyháza: Debreceni Egyetem Egészségügyi Főiskolai Kar, pp. 69-82.

33. Szoboszlai K. (2014): Lakásjellemzők Nyíregyházán 2012. Acta Medicinae et Sociologica, Vol. 5. No 12-13. Nyíregyháza.

34. Takács P., Fábián G. (2012): Egy lokális életminőség index kialakításának lépései. In: Fábián Gergely, Patyán László, Huszti Éva (szerk.) Életminőség Nyíregyházán. Nyíregyháza: Debreceni Egyetem Egészségügyi Föiskolai Kar, pp. 49-69.

35. Takács P., Fábián G. (2014): A nyíregyházi lakossági panelfelméréshez kapcsolódó életminőség vizsgálatok - Generációk. Acta Medicinae et Sociologica, Vol. 5. No 12-13. Nyíregyháza.

\section{Melléklet - változólista}

\begin{tabular}{|c|c|c|c|l|c|}
\hline $\begin{array}{c}2008 \\
\text { változó } \\
\text { neve }\end{array}$ & $\begin{array}{c}2010 \\
\text { változó } \\
\text { neve }\end{array}$ & $\begin{array}{c}2012 \\
\text { változó } \\
\text { neve }\end{array}$ & $\begin{array}{c}2015 \\
\text { változó } \\
\text { neve }\end{array}$ & \multicolumn{1}{|c|}{ Kérdés } & Csoport \\
\hline társ1 & társ2 & tka1 & tka1 & $\begin{array}{l}\text { Hány barátja van Önnek? 0 - nincs barátja; } \\
98 \text { - nincs válasz; 99 - NV }\end{array}$ & F1 \\
\hline társ13 & társ8 & tka6.1 & tka6.1 & $\begin{array}{l}\text { Milyen gyakran találkozik barátaival? 1 - } \\
\text { mindennap; 2 - 1-2 alkalommal hetente; 3 - } \\
\text { ritkábban,mint havonta; 5 - soha; 99 - NV }\end{array}$ & F1 \\
\hline társ13 & társ8h & tka6.2 & tka6.2 & $\begin{array}{l}\text { Milyen gyakran találkozik rokonaival? 1 - } \\
\text { mindennap; 2 - 1-2 alkalommal hetente; 3 - } \\
\text { ritkábban,mint havonta; 5 - soha; 99 - NV }\end{array}$ & F1 \\
\hline egá11 & egá11 & eá11 & eal1 & $\begin{array}{l}\text { Hogyan jellemezné egészs. állapotát? 1 - } \\
\text { nagyon jó; 2 - jó; 3 - elfogadható; 4 - rossz; } \\
5 \text { - nagyon rossz; 99 - NV }\end{array}$ & F2 \\
\hline gazd1 & gazd1 & gak1 & gak1 & $\begin{array}{l}\text { Dolgozik-e ön jelenleg? 1 - igen; 2 - nem; } \\
\text { 99-NV }\end{array}$ & F3 \\
\hline gazd25 & gazd25 & gak24 & gak16 \\
aa & $\begin{array}{l}\text { Mi jellemzi az ön fizetését? 1 - teljesen } \\
\text { elégedetlen; 2 - elégedetlen; 3 - közepesen } \\
\text { elégedett; 9 - elégedett; 5 - teljesen }\end{array}$ & F3 - NV \\
\hline
\end{tabular}




\begin{tabular}{|c|c|c|c|c|c|}
\hline ház26 & ház24 & hvk8 & hvk10 & $\begin{array}{l}\text { Mit mondana havi jövedelmére? } 1 \text { - csak } \\
\text { nagy nehézségek árán jövünk ki belöle; } 2 \text { - } \\
\text { nehézségek árán jövünk ki belöle; } 3 \text { - némi } \\
\text { nehézség árán jövünk ki belöle; } 4 \text { - kijövünk } \\
\text { belöle; } 5 \text { - viszonylag könnyen kijövünk } \\
\text { belöle; } 6 \text { - nagyon jól kijövünk belöle; } 99 \text { - } \\
\text { NV }\end{array}$ & $\mathrm{F} 4$ \\
\hline $\begin{array}{l}\text { ház19h } \\
\quad 3\end{array}$ & $\begin{array}{l}\text { ház15h } \\
\quad 6\end{array}$ & hvk6.6 & $\begin{array}{c}\text { hvk8. } \\
1\end{array}$ & $\begin{array}{l}\text { Hangos, zavaró környezet. } 1 \text { - igen; } 2 \text { - } \\
\text { nem; } 99 \text { - NV }\end{array}$ & F5 \\
\hline $\begin{array}{l}\text { ház19h } \\
\quad 4\end{array}$ & $\begin{array}{c}\text { ház15h } \\
3\end{array}$ & hvk6.3 & $\begin{array}{c}\text { hvk8. } \\
3\end{array}$ & $\begin{array}{l}\text { Sötét a környék, kevés a fény. } 1 \text { - igen; } 2 \text { - } \\
\text { nem; } 99 \text { - NV }\end{array}$ & F5 \\
\hline $\begin{array}{l}\text { ház19h } \\
\quad 8\end{array}$ & $\begin{array}{c}\text { ház15h } \\
\quad 4\end{array}$ & hvk6.4 & $\begin{array}{c}\text { hvk8. } \\
\quad 6\end{array}$ & $\begin{array}{l}\text { légszennyezés, vagy egyéb környezeti } \\
\text { probléma. } 1 \text { - igen; } 2 \text { - nem; } 99 \text { - NV }\end{array}$ & F5 \\
\hline $\begin{array}{l}\text { ház19h } \\
\quad 9\end{array}$ & $\begin{array}{l}\text { ház15h } \\
\quad 8\end{array}$ & hvk6.8 & $\begin{array}{c}\text { hvk8. } \\
7\end{array}$ & $\begin{array}{l}\text { Vandalizmus, bünözés a lakókörnyezetben. } \\
1 \text { - igen; } 2 \text { - nem; } 99 \text { - NV }\end{array}$ & F5 \\
\hline társ 12 & társ7 & tka5 & tka5 & $\begin{array}{l}\text { Milyen gyakran beszélget a } \\
\text { szomszédjaival? } 1 \text { - mindennap; } 2 \text { - 1-2 } \\
\text { alkalommal hetente; } 3 \text { - 1-2 alkalommal } \\
\text { havonta; } 4 \text { - ritkábban, mint havonta; } 5 \text { - } \\
\text { soha; } 99 \text { - NV }\end{array}$ & F5 \\
\hline $\begin{array}{l}\text { társ } 28 \\
\text { h3 }\end{array}$ & $\begin{array}{c}\text { társ } 23 \\
\text { h3 }\end{array}$ & tka9 & $\begin{array}{c}\text { tka14. } \\
3\end{array}$ & $\begin{array}{l}\text { Milyen gyakran találkozik barátaival } \\
\text { presszóban, sörözőben, nyilvános helyen? } 1 \\
\text { - hetente; } 2 \text { - havonta; } 3 \text { - évente } \\
\text { néhányszor; } 4 \text { - évente egyszer-kétszer; } 5 \text { - } \\
\text { ennél ritkábban, szinte soha; } 99 \text { - NV }\end{array}$ & F5 \\
\hline társ11 & társ6 & tka4.1 & tka4.1 & $\begin{array}{l}\text { Tagja-e sportklubnak? } 1 \text { - igen; } 2 \text { - nem; } 99 \\
\text { - NV }\end{array}$ & F6 \\
\hline $\begin{array}{l}\text { társ11 } \\
\text { h2 }\end{array}$ & $\begin{array}{l}\text { társ6h } \\
2\end{array}$ & tka4.2 & tka4.2 & $\begin{array}{l}\text { Tagja-e helyi, szomszédsági csoportnak? } 1 \text { - } \\
\text { igen; } 2 \text { - nem; } 99 \text { - NV }\end{array}$ & F6 \\
\hline $\begin{array}{l}\text { társ11 } \\
\text { h3 }\end{array}$ & $\begin{array}{l}\text { társ6h } \\
3\end{array}$ & tka4.3 & tka4.3 & $\begin{array}{l}\text { Tagja-e müvészeti csop.nak? } 1 \text { - igen; } 2 \text { - } \\
\text { nem; } 99 \text { - NV }\end{array}$ & F6 \\
\hline $\begin{array}{l}\text { társ11 } \\
\text { h4 }\end{array}$ & $\begin{array}{l}\text { társ6h } \\
\quad 4\end{array}$ & tka4.4 & tka4.4 & $\begin{array}{l}\text { Tagja-e vallási közösségnek? } 1 \text { - igen; } 2 \text { - } \\
\text { nem; } 99 \text { - NV }\end{array}$ & F6 \\
\hline $\begin{array}{l}\text { társ11 } \\
\text { h5 }\end{array}$ & $\begin{array}{l}\text { társ6h } \\
\quad 5\end{array}$ & tka4.5 & tka4.5 & $\begin{array}{l}\text { Tagja-e szabadidő klubnak? } 1 \text { - igen; } 2 \text { - } \\
\text { nem; } 99 \text { - NV }\end{array}$ & F6 \\
\hline szocp1 & szocp 1 & tre1.1 & tre1.1 & $\begin{array}{l}\text { (Kire számíthat?) Családtag. } 1 \text { - igen; } 2 \text { - } \\
\text { nem; } 99 \text { - NV }\end{array}$ & F7 \\
\hline $\begin{array}{l}\text { szocp1 } \\
\text { h2 }\end{array}$ & $\begin{array}{l}\text { szocp1 } \\
\text { h2 }\end{array}$ & $\operatorname{tre} 1.2$ & tre 1.2 & $\begin{array}{l}\text { (Kire számíthat?) Barátok. } 1 \text { - igen; } 2 \text { - nem; } \\
99 \text { - NV }\end{array}$ & F7 \\
\hline
\end{tabular}




\begin{tabular}{|c|c|c|c|l|c|}
\hline $\begin{array}{c}\text { szocp1 } \\
\text { h3 }\end{array}$ & $\begin{array}{c}\text { szocp1 } \\
\text { h3 }\end{array}$ & tre1.3 & tre1.3 & $\begin{array}{l}\text { (Kire számíthat?) Ismerösök. 1 - igen; 2 - } \\
\text { nem; 99 - NV }\end{array}$ & F7 \\
\hline $\begin{array}{c}\text { szocp1 } \\
\text { h4 }\end{array}$ & $\begin{array}{c}\text { szocp1 } \\
\text { h4 }\end{array}$ & tre1.4 & tre1.4 & $\begin{array}{l}\text { (Kire számíthat?) Hivatal. 1 - igen; 2 - nem; } \\
\text { 99 - NV }\end{array}$ & F7 \\
\hline $\begin{array}{c}\text { szocp1 } \\
\text { h5 }\end{array}$ & $\begin{array}{c}\text { szocp1 } \\
\text { h5 }\end{array}$ & tre1.5 & tre1.5 & $\begin{array}{l}\text { (Kire számíthat?) Szociális szolgáltató. 1 - } \\
\text { igen; 2 - nem; 99 - NV }\end{array}$ & F7 \\
\hline
\end{tabular}

F1 - Családi, baráti viszonyok

F2 - Egészségi állapot

F3 - Munka és aktivitás

F4 - Anyagi jólét

F5 - Környezet minősége

F6 - Lokális közösség

F7 - Személyes biztonság

\section{Szerzők}

Takács Péter PhD.: statisztikus, föiskolai docens

Debreceni Egyetem Egészségügyi Kar, 4400 Nyíregyháza, Sóstói u. 2-4.

Fábián Gergely PhD.: szociológus, kutató, főiskolai tanár

Debreceni Egyetem Egészségügyi Kar, 4400 Nyíregyháza, Sóstói u. 2-4.

Szigeti Fruzsina: PhD. hallgató

Debreceni Egyetem Bölcsészettudományi Kar Nevelés-és Müvelődéstudományi Doktori Program, 4032 Debrecen, Egyetem tér 1. 